\title{
Fruit Quality, Phytochemical Content, and Disease Severity of Muscadine Grapes Affected by Fungicide Applications
}

\author{
Barbara J. Smith* \\ United States Department of Agriculture, Agricultural Research Service, Thad Cochran Southern Horticultural Labora- \\ tory, P.O. Box 287, Poplarville, MS 39470, USA
}

\begin{abstract}
Muscadine grapes are high in phytochemicals beneficial to humans, such as resveratrol and ellagic acid. Four studies were conducted to explore the relationship between phytochemical content, berry quality, and disease control following full season or early season applications of fungicides. In each study foliar and fruit diseases were lower in the full season treatment compared to the control, and some treatments with fewer applications reduced fruit diseases to the same level as the full season treatment. In Study 1 the full season (9 applications) and azoxystrobin treatments ( 3 applications) resulted in significantly lower berry disease scores than the control treatment. There were no significant differences in vine vigor, foliar diseases, or bitter rot scores among treatments where fungicide applications were stopped at various preharvest intervals ranging from 56 to 0 days (Study 3), or in disease scores between the full season (8 applications) and early season treatments (4 applications) of six fungicide treatments (Study 4). Sugar levels were highest in berries from the full season, azoxystrobin, and control fungicide treatments, and berries from the least efficacious treatments for disease control had almost ten times as much resveratrol as those from the most efficacious treatments (Study 1). Ellagic acid and resveratrol levels were lower in berries from fungicide treated vines than from untreated vines (Study 3). The number of fungicide applications can be reduced to as few as four without an increase in berry disease scores; however, when diseases of muscadine grapes are controlled, levels of beneficial phytochemicals may decrease.
\end{abstract}

Keywords: Disease control, ellagic acid, muscadine, nutraceutical, resveratrol, Vitis rotundifolia.

\section{INTRODUCTION}

Muscadine grapes (Vitis rotundifolia Michx., synonym Muscadinia rotundifolia (Michx.) Small) are native to the southeastern U.S. [1]. These grapes are very productive and most commercial cultivars are tolerant to Pierce's Disease, a bacterial disease which limits the production of $V$. vinifera grapes in many parts of the southeastern U. S. [2]. The fruit has a distinctive taste and aroma, and the juice is sweet and low in acidity. Muscadine grapes are high in phytochemicals such as resveratrol and ellagic acid that have been shown to prevent heart disease and cancer in humans [3-6]. Resveratrol is a phenolic compound that has been shown to lower serum lipids [7], inhibit platelet aggregation in the blood $[8,9]$, and inhibit oxidation of human low-density lipoprotein [10]. The potential value of resveratrol in the prevention and treatment of cancer has been suggested by various laboratory assays in which resveratrol inhibited cellular events associated with tumor initiation, promotion and progression [11-13]. Ellagic acid has been associated with health benefits in humans including the prevention of cancer. It is absent in other Vitis species but is present in high levels in muscadine grapes and is found in other fruits including raspberry, strawberry, and blackberry [14]. In muscadine grapes, ellagic acid is expressed as free ellagic acid, ellagic acid glycosides,

*Address correspondence to this author at the United States Department of Agriculture, Agricultural Research Service, Thad Cochran Southern Horticultural Laboratory, P.O. Box 287, Poplarville, MS 39470 USA; Tel: (601) 403-8446; Fax: (601) 795-4995; Email: Barbara.Smith@ars.usda.gov and ellagitannins [15]. Pezzuto [16] concluded "that regular daily consumption of grapes could help maintain heart health, and potentially help to protect against the onset of aging, as well as the onset of some diseases associated with aging, such as certain cancers and neurodegeneration." This statement certainly applies to muscadine grapes that have many of the same phytochemicals as other Vitis species and also have high levels of ellagic acid.

Resveratrol and other stilbenes found in a number of plant families are considered to be phytoalexins, i.e., compounds produced by the plant as a chemical defense response to diseases, environmental stress, preharvest treatment with a plant activator, or genetic manipulation [16-22]. Resveratrol production by Vitis $\mathrm{sp}$. occurs in response to fungal infection, ultraviolet irradiation, and mechanical injury [23]. The association between phytoalexins and disease resistance in Vitis sp. has been well-documented [24, 25]. Magee et al. [26] reported that the level of resveratrol in muscadine grapes is reduced when fruit diseases are controlled by fungicide applications.

Muscadine grapes generally are more resistant to diseases than bunch grapes [27, 28]; however the warm humid environment of the southeastern U. S. favors development of fungi that cause fruit and foliar diseases. Important fruit diseases of muscadine grapes in south Mississippi include: bitter rot [caused by Greenaria uvicola (Berk. \& Curt.) Punithalingam], Macrophoma rot [caused by Botryosphaeria dothidea (Moug. Ex Fr.) Ces. \& deNot.], ripe rot [caused by Colletotrichum gloeosporioides (Penz.) Penz. \& Sacc. and C. 
acutatum Simmonds ex Simmonds], and black rot [caused by Guignardia bidwellii (Ellis) Viala \& Ravaz. f. muscadinii Luttrell] [2, 29]. Foliar diseases such as bitter rot leaf spot, angular leaf spot [caused by Mycosphaerella angulata Jenkins (anamorph Cercospora brachypus Ell. \& Ev.)] [2] and black rot leaf spot usually are not severe enough to significantly reduce vine vigor of most cultivars. Control of berry diseases of muscadine grapes is necessary to minimize yield loss and to ensure the highest quality fresh-market berries. Fungicides are very effective for control of both fruit and foliar diseases, but they are expensive to purchase and apply. This cost can be lowered if effective fungicides are applied on a reduced schedule while maintaining effective disease control. However, a previous study [26] indicated that effective fruit disease control may result in reduced quantities of resveratrol and other beneficial phytochemicals in the fruit. Therefore, it is desirable to identify fungicide application schedules that are effective in reducing berry diseases without reducing phytochemical content.

The objectives of the four studies in this paper were to compare the efficacy of fungicides applied at regular intervals over a full season to those applied on a reduced schedule for control of fruit and foliar diseases of muscadine grapes and to determine the effect of the individual fungicides and various spray schedules on fruit yield, quality, and phytochemical composition. In the first study, the efficacy of a full season fungicide spray program composed of four fungicides was compared to that of each individual fungicide on control of fruit and foliar diseases and on fruit quality. Quality parameters included $\mathrm{pH}$, soluble solid concentration (SSC), titratable acidity (TA), SSC/TA ratio, and sugar, organic acid, and phytochemical content. The second study compared the efficacy of five fungicides for control of fruit and foliar diseases. The objective of the third study was to determine the effect of various fungicide application schedules on fruit and foliar diseases and to determine the relationship between disease incidence and phytochemical content. The fourth study compared the efficacy of four fungicides applied individually or alternated with other fungicides using either a full season or an early season schedule.

\section{MATERIALS AND METHODOLOGY}

\section{Vineyard Management}

Vines of the bronze-fruited muscadine grape cultivars, 'Carlos', 'Doreen', and 'Summit', were established in a randomized complete block design consisting of four or five rows of each cultivar at the U.S. Department of Agriculture, Agricultural Research Service (USDA-ARS) Thad Cochran Southern Horticultural Research Unit vineyards in McNeill, Mississippi. Vines were drip-irrigated and maintained following cultural practices recommended by the Mississippi State University Cooperative Extension Service [30]. Vines were 9 to 12 years old, and each plot consisted of a single vine trained to a Geneva double curtain trellis with $6 \mathrm{~m}$ arms. Treatments were randomly assigned within each row of each cultivar. Fungicides were applied with a tractor-mounted air blast mist sprayer (Study 1) or high pressure hand gun sprayer (Studies 2 - 4).

\section{Foliar and Fruit Disease Ratings}

Foliar disease ratings were made just before harvest using a visual rating scale. Symptoms of bitter rot leaf spot, black rot leaf spot, angular leaf spot and Pierce's disease were each rated on a scale of $0=$ no symptoms to $5=$ severe symptoms. Fully ripe berries were hand-harvested into field lugs, and random 1-L samples were taken from each lug for disease ratings and chemical analyses. Two independent observers scored 25 berries individually for each of four berry rot diseases (bitter rot, ripe rot, Macrophoma rot and black rot) on a scale of $0=$ no symptoms, $1=$ very mild symptoms, 2 = moderate symptoms, and 3 = severe symptoms, berries inedible [29].

\section{Quality Analysis}

Soluble solid concentration (\%) (SSC) of the juice was measured using an Atag $\mathrm{N}-20$ hand refractometer at $20{ }^{\circ} \mathrm{C}$, and results expressed in ${ }^{\circ}$ Brix. Titratable acidity (TA) (tartaric acid in $\mathrm{g} / \mathrm{L}$ ) was measured by placing $5 \mathrm{ml}$ of juice into $100 \mathrm{ml}$ of deionized water and titrating with $0.1 \mathrm{~N}$ sodium hydroxide to an end point of $\mathrm{pH}$ 8.2. The results were also expressed as the ratio between SSC/TA which is a measure of the maturity of fruit at harvest.

Resveratrol, ellagic acid, sugar, and organic acid levels in the fruit were determined by high-performance liquid chromatography (HPLC). Identification and quantification were done by comparison of sample peaks with those of external standards. Fruit was harvested at the full ripe stage, immediately frozen, and held for analysis. Berries were thawed, cut in half longitudinally, seeds removed, and pulp and freeflowing juice separated from the skins by finger pressure. Pulp/juice samples were frozen and lyophyllized. Skins were rinsed with deionized water, dried at $35^{\circ} \mathrm{C}$ under forced air draft and ground to a fine powder in a laboratory mill. The dried components were held at $-20{ }^{\circ} \mathrm{C}$ until analyzed.

Samples were extracted for resveratrol and ellagic acid analysis using a procedure similar to that described by Dercks and Creasy [31]. One gram of sample was homogenized (Brinkman PT1035) for $30 \mathrm{sec}$ in $20 \mathrm{~mL}$ of $80 \%(\mathrm{v} / \mathrm{v})$ methanol. The homogenate was sonicated $30 \mathrm{~min}$ and centrifuged at $2000 \mathrm{~g}$ for $20 \mathrm{~min}$. The supernatant was transferred to a graduated conical tube and concentrated to $4 \mathrm{~mL}$ by evaporating the methanol in a water bath at $40{ }^{\circ} \mathrm{C}$ under nitrogen. Six $\mathrm{mL}$ of $3 \% \mathrm{NaHCO}_{3}$ was added and the aqueous phase extracted twice with $10 \mathrm{~mL}$ of ethyl acetate. Ethyl acetate fractions were combined and evaporated to dryness under nitrogen at $40{ }^{\circ} \mathrm{C}$. Resveratrol was analyzed by GC/MS (Hewlett-Packard 5989A mass spectrometer coupled to a Hewlett-Packard 5890 Series II gas chromatograph, Palo Alto, CA) with a DB5.625 capillary column (J\&W Scientific, Inc., Folsom, CA), $30 \mathrm{~m}$ long x $0.25 \mathrm{~mm}$ I.D. x 0.25 $\mu \mathrm{m}$ film. One $\mu \mathrm{L}$ (splitless) injection of derivatized solution was made with the following temperature conditions: injection port held constant at $250{ }^{\circ} \mathrm{C}$, oven temperature held at $120{ }^{\circ} \mathrm{C}$ for $1 \mathrm{~min}$ then ramped at $20^{\circ} \mathrm{C} / \mathrm{min}$ to $325{ }^{\circ} \mathrm{C}$ and held at this temperature for $5 \mathrm{~min}$. The ion source was at 250 ${ }^{\circ} \mathrm{C}$ and the quadruple at $100{ }^{\circ} \mathrm{C}$. Helium at a flow rate of 1.8 $\mathrm{mL} / \mathrm{min}$ was the carrier gas. The retention time of derivatized standard resveratrol at these conditions was $12.10 \pm$ $0.02 \mathrm{~min}$.

Dried muscadine grape extracts were dissolved in methanol and $50 \mu \mathrm{L}$ aliquots were dried under nitrogen and treated with $\quad 100 \mu \mathrm{L}$ of $1: 1$ dimethylformamide:N,O-bis- 
(trimethylsilyl)trifluoroacetamide (Pierce, Rockford, IL). The solutions were heated at $70^{\circ} \mathrm{C}$ for $30 \mathrm{~min}$ prior to injection. Resveratrol was quantified on the tris-trimethylsilyl derivative $\mathrm{m} / \mathrm{z}$ 444. Resveratrol was detected with a UV-Vis at $310 \mathrm{~nm}$ and ellagic acid was detected at $255 \mathrm{~nm}$. Solutions of resveratrol and ellagic acid (Sigma, St. Louis, MO) in methanol were prepared for the calibration curve, and $50 \mu \mathrm{L}$ of each was treated in the same fashion as were the samples. For each sample, peak area was measured and concentration calculated from the standard curve. Concentration of resveratrol is reported as $\mu \mathrm{g} / \mathrm{g}$ on a dry weight basis for each component and ellagic acid is reported as $\mathrm{mg} / \mathrm{L}$.

Sugars and organic acids were determined following a modification of the procedure reported by Kalt and McDonald [32]. Samples for HPLC analysis of sugars and organic acids were prepared by homogenizing $20 \mathrm{~g}$ of the frozen juice/plup (Brinkmann PT 10/35 Homogenizer) and centrifuging to remove solids. Six $\mathrm{ml}$ of the supernatant was diluted with 2 parts deionized water and passed through a SepPak 18 cartridge that had been rinsed with $5 \mathrm{ml}$ methanol followed by $5 \mathrm{ml}$ of deionized water. The last $4 \mathrm{ml}$ of juice effluent was collected and filtered through a Millex-HV Filter, $0.45 \mu \mathrm{m}$, syringe filter (EMD Millipore Corporation, Billerica, MA). Sugars in a $20-\mu 1$ sample were separated with $75 \%$ acetonitrile $/ 25 \%$ water $(2.5 \mathrm{ml} \cdot \mathrm{min}-1)$ on a Supelcosil LC-NH2 HPLC Column $(5 \mu \mathrm{m}$ particle size, $\mathrm{L} \times$ I.D. $25 \mathrm{~cm}$ $\times 4.6 \mathrm{~mm}$ ) (Sigma-Aldrich Co, St. Louis, MO) and detected by their refractive index using a Waters 401 Refractive Index Detector. Organic acids in a 20- $\mu 1$ sample were separated on a Aminex HPX-87H organic acid HPLC column (Bio-Rad Laboratories, Inc., Richmond, CA). The mobile phase was $0.005 \mathrm{M} \mathrm{H}_{2} \mathrm{SO}_{4}$ sulfuric acid with at a flow rate of 0.6 $\mathrm{ml} \cdot \mathrm{min}-1$ at $35^{\circ} \mathrm{C}$. Organic acids were detected at $214 \mathrm{~nm}$ with a Waters 486 Tunable Absorbance detector. Sugars and organic acids were identified by comparison with retention times of pure standards (Sigma Chemical Co., St. Louis).

\section{Study 1}

Vines of the cultivars, 'Summit', 'Doreen', and 'Carlos', were treated with four fungicides (myclobutanil, azoxystrobin, benomyl, and captan) applied with a tractormounted air blast mist sprayer from early bloom until just before harvest (Table 1). Vines in the "Full" treatment were treated with the following fungicides applied in order on a 10-day interval: myclobutanil, benomyl, azoxystrobin, myclobutanil, captan, azoxystrobin, captan, azoxystrobin, and captan for a total of nine applications to 'Summit' and 'Carlos'. An additional application of azoxystrobin was applied to 'Doreen'. Control vines received no fungicide applications.

\section{Study 2}

Five fungicides (myclobutanil, azoxystrobin, tebuconazole, fenhexamid, and a commercial mixture of cyprodinil and fludioxonil) were applied to vines of the cultivar, 'Carlos' (Table 1). Fungicides were applied to only one side of each vine in any effort to determine if there was any evidence of systemic movement of any of the fungicides from one side of the vine to the other. Myclobutanil, azoxystrobin, tebuconazole, fenhexamid, and cyprodinil are considered locally systemic. Each of the five fungicides was applied individually at 30-day intervals as indicated in Table 1. A full season treatment of 12 applications in which three fungicides, myclobutanil, azoxystrobin, and tebuconazole, were alternated on10-day interval was also included.

\section{Study 3}

Three fungicides (myclobutanil, azoxystrobin, and tebuconazole) were applied to vines of the cultivars, 'Doreen' and 'Summit', on a season long schedule alternating the three fungicides in sequence (Table 1). The fungicides were applied to only one side of each vine. Applications were made every ten days beginning at bloom and were discontinued at various intervals $(56,42,28,14,7,4,2,1$, and 0 days) before harvest. The number of applications varied from six (two of each fungicide) to 12 (four of each fungicide) depending on the interval between the last fungicide application and harvest. Each treatment and an unsprayed control were replicated five times.

\section{Study 4}

Four fungicides (azoxystrobin, tebuconazole, myclobutanil, and a commercial mixture of cyprodinil and fludioxonil) were applied to vines of 'Carlos' and 'Summit' (Table 1). In the full season treatments, each fungicide was applied starting at bloom and continuing on a 10-day schedule until harvest for a total of eight applications. For the early season treatments, fungicide applications were discontinued to one side of each vine after the fourth application. Each fungicide was also alternated with each of the other three fungicides and applied on the same 10-day schedule as the individual fungicides. All four fungicides were also applied in sequence for a total of two applications of each of the four fungicides over the full season and one application of each fungicide in the early season treatment. No fungicides were applied to the vines in the control treatment. Each treatment was replicated four times.

\section{Statistical Analysis}

Each experiment was designed as a randomized complete block. Data were analyzed using SAS statistical software (version 8.2; SAS Institute, Cary, NC). Treatment means were separated at the $5 \%$ significance level by Fisher's protected least significance difference test.

\section{RESULTS}

\section{Study 1}

There were significant differences among the three cultivars and the six fungicide treatments in vine vigor and foliar and fruit disease scores (Table 2). 'Carlos' received higher bitter rot leaf spot scores and lower vine vigor scores than 'Summit' and 'Doreen'. 'Summit' received lower black rot leaf spot scores than the other two cultivars. Control vines which received no fungicide application and those treated with myclobutanil had the highest bitter rot leaf spot and black rot leaf spot scores, while vines receiving the full season fungicide treatment had the lowest foliar disease scores and the highest vine vigor score. There were no differences in angular leaf spot or Pierce's disease scores due to 
Table 1. Fungicides Applied to Muscadine Grape Cultivars Grown at McNeill, MS

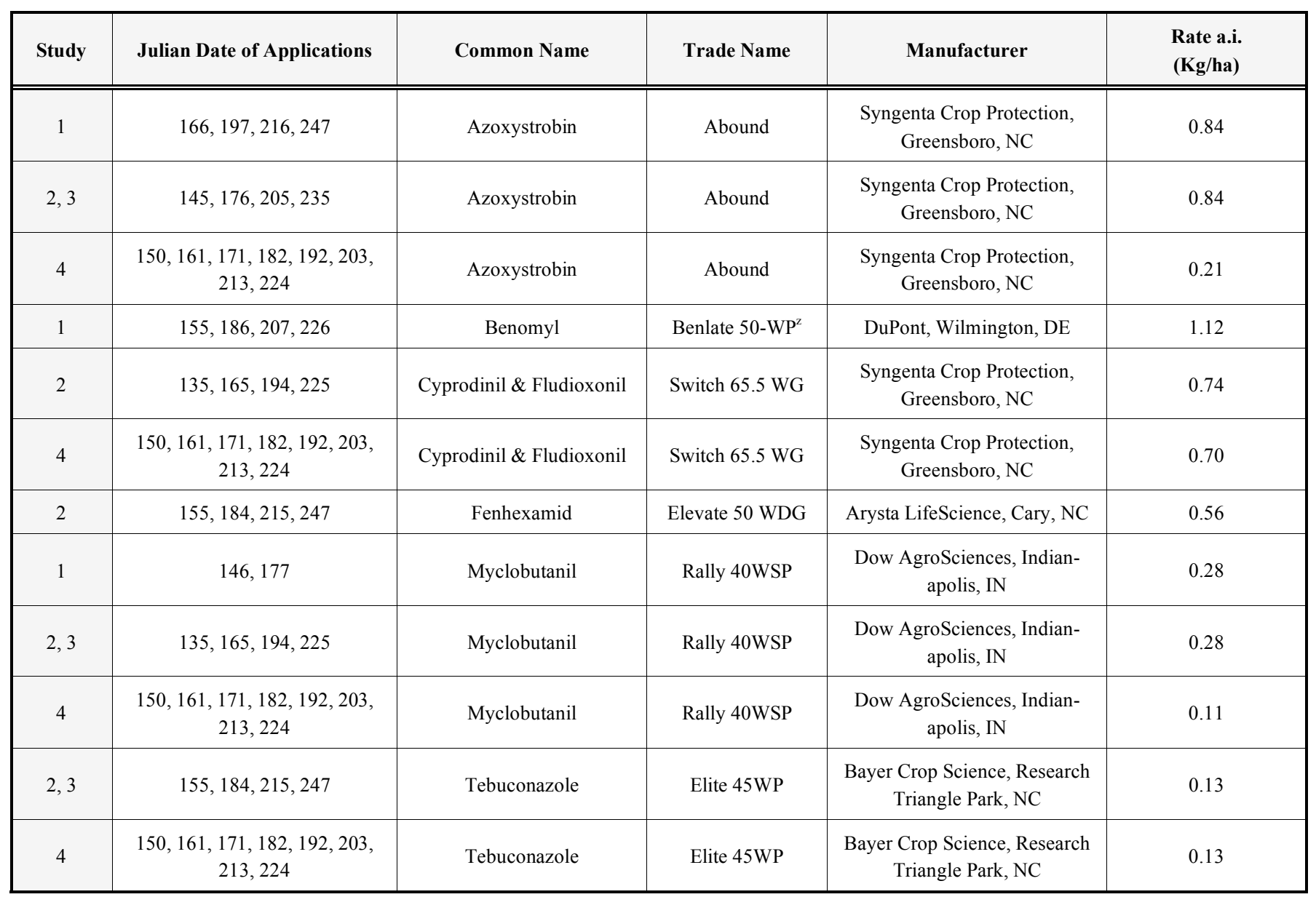

${ }^{\mathrm{z}}$ The registration for Benlate in the U.S.A. was canceled in 2001. It was included in this trail for comparison with earlier studies.

Table 2. Study 1. Cultivar and Fungicide Treatment Effects on Foliar Disease and Vine Vigor Scores ${ }^{\mathrm{x}}$, Percentage of Berries with No Disease Symptoms, and Berry Disease Scores ${ }^{y}$ of Three Muscadine Grape Cultivars Grown at McNeill, MS

\begin{tabular}{|c|c|c|c|c|c|c|c|c|c|c|c|c|c|c|c|c|c|c|c|}
\hline \multirow{3}{*}{$\begin{array}{c}\text { Cultivar } \\
\text { Carlos }\end{array}$} & \multicolumn{7}{|c|}{ Foliar Disease and Vine Vigor } & \multicolumn{12}{|c|}{ Fruit Disease Assessments } \\
\hline & \multirow{2}{*}{$\begin{array}{c}\mathbf{N} \\
46\end{array}$} & \multicolumn{2}{|c|}{$\begin{array}{l}\text { Bitter Rot } \\
\text { Leaf Spot }\end{array}$} & \multicolumn{2}{|c|}{$\begin{array}{l}\text { Black Rot } \\
\text { Leaf Spot }\end{array}$} & \multicolumn{2}{|c|}{$\begin{array}{l}\text { Vine } \\
\text { Vigor }\end{array}$} & \multicolumn{2}{|c|}{$\begin{array}{c}\text { No symptoms } \\
(\%)\end{array}$} & \multicolumn{2}{|c|}{ Total } & \multicolumn{2}{|c|}{$\begin{array}{c}\text { Bitter } \\
\text { Rot }\end{array}$} & \multicolumn{2}{|c|}{$\begin{array}{c}\text { Macrophoma } \\
\text { Rot }\end{array}$} & \multicolumn{2}{|c|}{$\begin{array}{l}\text { Ripe } \\
\text { Rot }\end{array}$} & \multicolumn{2}{|c|}{$\begin{array}{c}\text { Black } \\
\text { Rot }\end{array}$} \\
\hline & & 3.80 & $a^{z}$ & 1.98 & $\mathrm{a}$ & 3.74 & $b$ & 78.7 & a & 2.10 & $c^{z}$ & 0.54 & $\mathrm{c}$ & 0.23 & $\mathrm{c}$ & 0.05 & $\mathrm{~b}$ & 0.27 & $\mathrm{a}$ \\
\hline Doreen & 25 & 1.80 & $\mathrm{c}$ & 1.88 & $\mathrm{a}$ & 4.32 & a & 46.1 & $b$ & 3.82 & $\mathrm{a}$ & 1.54 & $\mathrm{a}$ & 1.40 & $\mathrm{a}$ & 0.09 & $\mathrm{a}$ & 0.15 & $\mathrm{~b}$ \\
\hline Summit & 22 & 2.50 & $\mathrm{~b}$ & 0.18 & $\mathrm{~b}$ & 4.23 & $\mathrm{a}$ & 50.4 & $b$ & 3.33 & $\mathrm{~b}$ & 0.98 & $\mathrm{~b}$ & 1.07 & $\mathrm{~b}$ & 0.05 & $b$ & 0.26 & $\mathrm{a}$ \\
\hline \multicolumn{20}{|c|}{ Treatment } \\
\hline Full & 16 & 0.88 & $\mathrm{~d}$ & 0.81 & $\mathrm{c}$ & 4.69 & $\mathrm{a}$ & 97.4 & $\mathrm{a}$ & 1.60 & $\mathrm{e}$ & 0.29 & $\mathrm{~d}$ & 0.39 & $\mathrm{c}$ & 0.04 & bc & 0.20 & $\mathrm{c}$ \\
\hline Azoxystrobin & 16 & 2.88 & $\mathrm{c}$ & 1.38 & $\mathrm{~b}$ & 4.00 & $\mathrm{~b}$ & 79.2 & $\mathrm{~b}$ & 1.93 & $\mathrm{~d}$ & 0.35 & $\mathrm{~d}$ & 0.45 & $\mathrm{c}$ & 0.04 & $\mathrm{c}$ & 0.24 & $\mathrm{abc}$ \\
\hline Benomyl & 16 & 2.88 & $\mathrm{c}$ & 1.38 & $\mathrm{~b}$ & 3.88 & b & 53.2 & $\mathrm{c}$ & 3.46 & $\mathrm{~b}$ & 1.22 & $\mathrm{~b}$ & 0.99 & $\mathrm{a}$ & 0.07 & $a b$ & 0.21 & $\mathrm{bc}$ \\
\hline Captan & 15 & 3.40 & bc & 1.53 & $\mathrm{~b}$ & 4.13 & $a b$ & 58.5 & c & 3.05 & $\mathrm{c}$ & 1.04 & $\mathrm{c}$ & 0.81 & $\mathrm{~b}$ & 0.06 & $a b c$ & 0.24 & $a b c$ \\
\hline Myclobutanil & 14 & 3.86 & $\mathrm{ab}$ & 2.07 & $\mathrm{a}$ & 3.71 & $\mathrm{~b}$ & 39.1 & d & 3.79 & $\mathrm{a}$ & 1.42 & $\mathrm{a}$ & 1.06 & $\mathrm{a}$ & 0.05 & $a b c$ & 0.26 & $a b$ \\
\hline Control & 16 & 4.00 & $\mathrm{a}$ & 2.06 & $\mathrm{a}$ & 3.63 & $\mathrm{~b}$ & 40.7 & d & 3.79 & $\mathrm{a}$ & 1.38 & $\mathrm{a}$ & 1.06 & $\mathrm{a}$ & 0.08 & $\mathrm{a}$ & 0.27 & a \\
\hline
\end{tabular}

${ }^{\mathrm{x}}$ Foliar disease severity rated on a scale of $0=$ no foliar symptoms to $3=$ severe symptoms. Vine vigor rated of scale of $0=$ vine dead to $5=$ most vigorous vine.

${ }^{\mathrm{y}}$ Fruit disease severity rated on 25 berries on a scale of $0=$ no symptoms to $3=$ severe symptoms, berry inedible.

${ }^{\mathrm{z}}$ Means followed by different letters within a column and within cultivar and treatment are significantly different $(P=0.05)$ based on Fisher's least significant difference (LSD). 
fungicide treatments (data not shown). There was not a significant interaction between cultivar and fungicide treatment for foliar disease or vine vigor scores.

'Carlos' had the lowest total fruit disease, bitter rot, and Macrophoma rot scores, as well as the highest percentage of berries with no visible disease symptoms. 'Doreen' had the highest total disease, bitter rot, Macrophoma rot, and ripe rot scores, and the lowest black rot score. The full season treatment resulted in the lowest total disease score and the most berries with no visible symptoms. Berries from the full season and the azoxystrobin treatments had significantly lower total disease, bitter rot and Macrophoma rot scores and more berries with no visible symptoms. Berries from the myclobutanil and control treatments received the highest total disease and bitter rot scores and had the fewest berries with no visible symptoms.

'Carlos' had significantly higher yield than 'Summit' or 'Doreen', while 'Carlos' berries were the smallest and 'Summit' berries were the largest of the three cultivars (Table 3). 'Doreen' berries had more than four times higher total resveratrol than the other two cultivars. 'Carlos' berries had the highest total organic acid and total sugar content. Vines receiving the full season, azoxystrobin, and myclobutanil fungicide treatments had higher yields than untreated vines when averaged across the three cultivars, but there were no significant differences in berry size due to fungicide treatment (Table 3).

Significant differences due to fungicide treatments were found in several quality parameters including $\mathrm{pH}$, TA, sugars, acids, and resveratrol content (Table 3). Berries receiving the full season, azoxystrobin, and control fungicide treatments had the highest sugar levels (fructose, glucose, and total). Total resveratrol content was lower in berries from the full season and azoxystrobin treatments than in berries from the other fungicide treatments. There was a significant cultivar by fungicide interaction in $\mathrm{pH}$, fructose, glucose, total sugars, and cis- and total resveratrol levels. 'Doreen' berries from the least efficacious treatments (control, myclobutanil, captan, and benomyl) had almost ten times as much resveratrol as those from the most efficacious full and azoxystrobin treatments. Resveratrol content of 'Carlos' and 'Summit' berries was significantly lower than that of 'Doreen', but 'Summit' berries receiving the control and captan treatments still had higher resveratrol levels than berries from the other treatments.

\section{Study 2}

Only one side of each vine in this study received fungicide treatments, i.e. "spray" treatments. The other side of each vine was not sprayed with the fungicide, i.e. "no spray" treatment. There were no significant differences in vine vigor scores between the sprayed and not sprayed side of vines in any treatment (Table 4). There were significant differences in bitter rot leaf spot disease scores between the sprayed and not sprayed sides of vines receiving the full season and azoxystrobin treatments; however, the bitter rot score on the not sprayed side of the vines was not significantly lower than that of the control vines. The most vigorous vines were those that received full season treatment on both the sprayed and not sprayed sides of the vines. There were no differences in black rot leaf spot, angular leaf spot, or Pierce's disease scores due to fungicide treatments (data not shown).

The percentage of berries with no disease symptoms was significantly different between the sprayed and not sprayed sides of the vines in all fungicide treatments in Study 2 except for the tebuconazole treatment (Table 4). Berries from the sprayed side of vines receiving the cyprodinil and fludioxonil combination treatment had lower total disease and bitter rot scores than berries from the not sprayed side of the vines. Bitter rot scores of berries from the sprayed side of the full treatment were less than half the score from the not sprayed side of vines in the full treatment. There were no significant differences due to fungicide treatment in ripe rot or black rot disease scores (data not shown).

There were no significant differences in vine vigor, bitter rot leaf spot, or Macrophoma fruit rot scores between the untreated control vines and the "not sprayed" side of the fungicide treated vines. The only significant difference between the untreated control vines and the "not sprayed" side of the fungicide treated vines occurred in the bitter rot and total disease scores and the percentage of berries with no disease symptoms from the azoxystrobin treated vines. The difference between the 'not sprayed' and 'sprayed' sides of the azoxystrobin treated vines was significant for the percentage of berries with no disease symptoms but not for the bitter rot and total disease scores.

\section{Study 3}

'Doreen' vines received significantly higher vigor ratings and black rot leaf spot severity ratings than 'Summit' vines (Table 5), but there were no differences between the cultivars in bitter rot leaf spot, angular leaf spot, or Pierce's Disease ratings (data not shown). One side of each vine in the fungicide treatments received fungicide applications (spray treatment) while the other side did not (no spray treatment). Vines in the control treatment did not receive any fungicide applications. While both bitter rot and black rot leaf spot ratings were low, their ratings on the control vines and on the not sprayed side of fungicide treated vines were significantly higher than on the sprayed side. There were no significant differences in vine vigor or foliar diseases scores due to the number of days between the last fungicide application and harvest for either cultivar (data not shown).

Bitter rot and total fruit disease severity scores were lower and the percentage of asymptomatic berries and ripe rot score were higher for 'Doreen' than for 'Summit' (Table 5). Berries from the sprayed side of vines had more asymptomatic berries and lower bitter rot, Macrophoma rot, and total disease scores than berries from the unsprayed side of vines or from the control vines. Among berries from the sprayed side of vines, 'Doreen' had more asymptomatic berries and lower bitter rot and lower total disease scores than 'Summit'; however, 'Doreen' berries had higher Macrophoma rot and ripe rot scores than the 'Summit' berries. Among the berries from the sprayed side of the vines there were no significant differences in the percentage of asymptomatic berries or in the bitter rot disease scores due to the number of days between the last fungicide application and harvest. There were significant differences in the Macrophoma rot, ripe rot, and total diseases scores due to the 
Table 3. Study 1. Main effects and Interactions of Cultivar and Fungicide Treatments on Yield, Berry Size, Total (Skin) Resveratrol, Total Acids, Total Sugars, \% Soluble Solid Content, pH, Titratible Acidity, Fructose, Glucose, and Organic Acids (Tartaric, Citric, Malic). Content of 'Carlos', 'Doreen', and 'Summit' Muscadine Grapes Grown at McNeill, MS

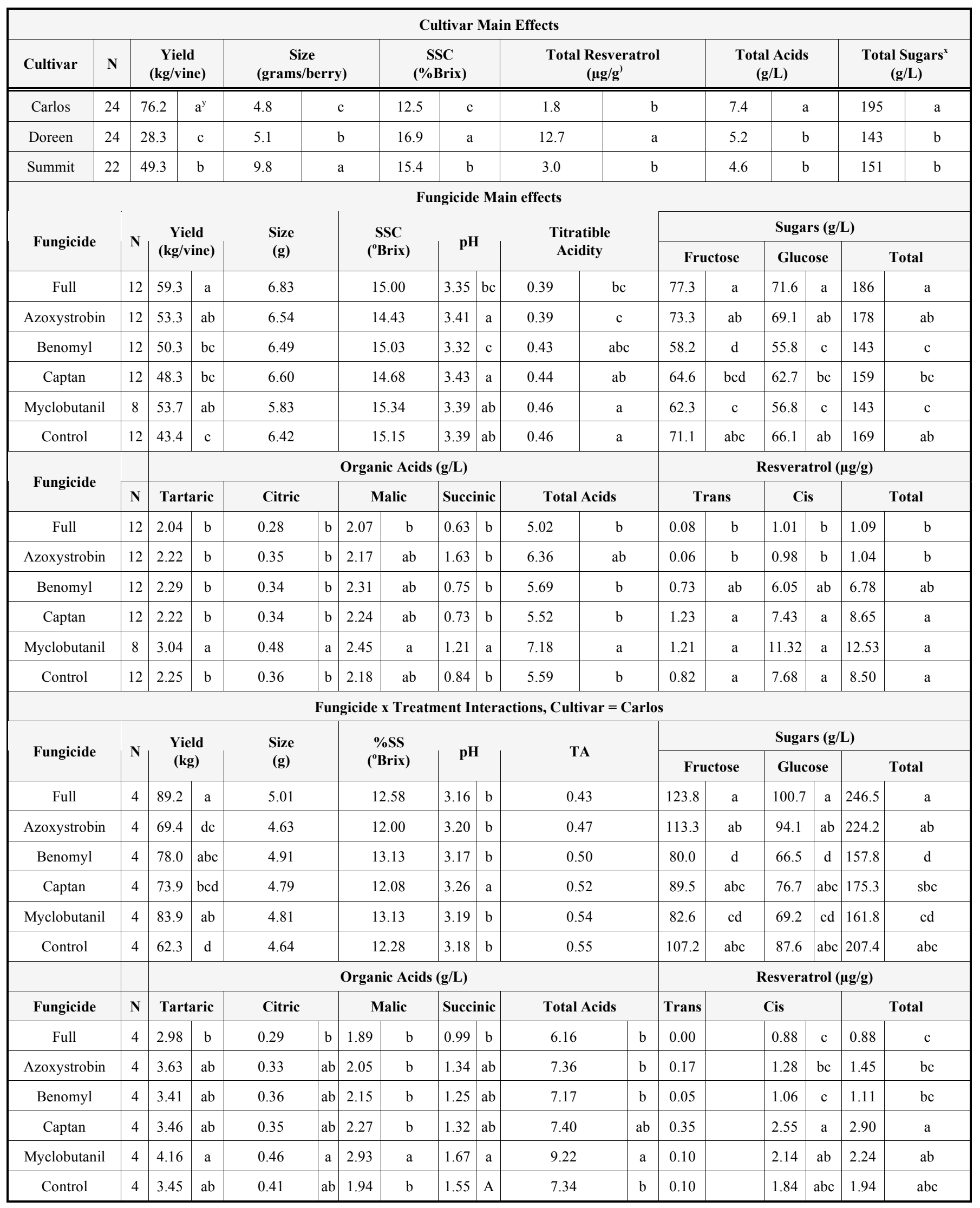


(Table 3) contd....

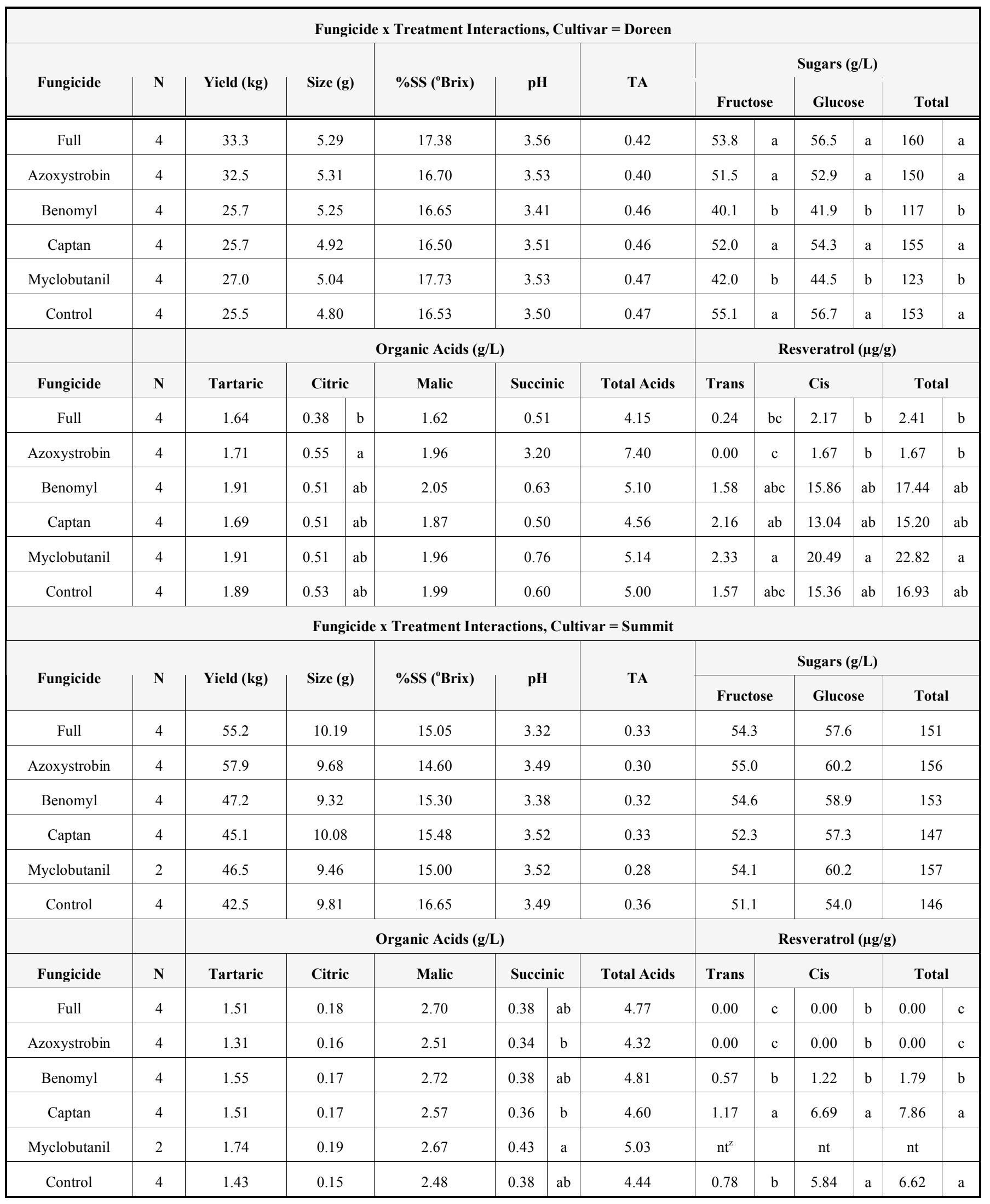

${ }^{\mathrm{x}}$ Total sugars include fructose, glucose, and sucrose.

${ }^{y}$ Means followed by different letters within a column are significantly different $(\mathrm{P}=0.05)$ based on Fisher's LSD.

${ }^{\mathrm{z}} \mathrm{nt}=$ not tested. 
Table 4. Study 2. Effect of Five Fungicides Applied to the Muscadine Cultivar, 'Carlos', on Vine Vigor, Foliar Disease and Berry Diseases. Fungicides were Applied to Only One Side of Each Vine (Spray Treatment) and Not to the other Side (No Spray Treatment). Vines in the Control Treatment were not Sprayed with Fungicides

\begin{tabular}{|c|c|c|c|c|c|c|c|c|c|c|c|c|c|c|}
\hline \multirow{3}{*}{$\begin{array}{c}\text { Fungicide } \\
\text { Full }\end{array}$} & \multirow{3}{*}{$\begin{array}{c}\text { Application } \\
\text { No }\end{array}$} & \multicolumn{5}{|c|}{ Vine and Foliar Disease Assessments ${ }^{x}$} & \multicolumn{8}{|c|}{ Berry Disease Assessments ${ }^{y}$} \\
\hline & & \multirow{2}{*}{$\begin{array}{c}\mathbf{N} \\
6\end{array}$} & \multicolumn{2}{|c|}{ Vine Vigor } & \multicolumn{2}{|c|}{$\begin{array}{l}\text { Bitter Rot } \\
\text { Leaf Spot }\end{array}$} & \multicolumn{2}{|c|}{$\begin{array}{c}\% \text { No } \\
\text { Symptoms }\end{array}$} & \multicolumn{2}{|c|}{$\begin{array}{c}\text { Total } \\
\text { Disease }\end{array}$} & \multicolumn{2}{|c|}{$\begin{array}{c}\text { Bitter } \\
\text { Rot }\end{array}$} & \multicolumn{2}{|c|}{$\begin{array}{c}\text { Macrophoma } \\
\text { Rot }\end{array}$} \\
\hline & & & 5.8 & $a b^{z}$ & 0.9 & $a b$ & 8.5 & cdef & 31.2 & abcd & 15.0 & abcd & 5.3 & $a b c$ \\
\hline Full & Spray & 6 & 6.2 & a & 0.0 & $\mathrm{~d}$ & 11.9 & $\mathrm{a}$ & 20.0 & $\mathrm{~d}$ & 7.2 & $\mathrm{f}$ & 2.9 & bcd \\
\hline Azoxystrobin & No & 4 & 5.0 & bc & 1.1 & a & 9.1 & bcd & 28.4 & bcd & 12.6 & bcdef & 2.1 & $\mathrm{~cd}$ \\
\hline Azoxystrobin & Spray & 4 & 5.0 & $\mathrm{bc}$ & 0.3 & $\mathrm{~cd}$ & 12.8 & $\mathrm{a}$ & 20.1 & $\mathrm{~d}$ & 8.4 & def & 2.1 & $\mathrm{~cd}$ \\
\hline Fenhexamid & No & 5 & 5.0 & $\mathrm{bc}$ & 0.9 & $\mathrm{ab}$ & 8.3 & cdef & 33.1 & $\mathrm{abc}$ & 14.8 & abcd & 3.2 & bed \\
\hline Fenhexamid & Spray & 5 & 5.0 & $\mathrm{c}$ & 0.6 & abcd & 4.8 & $\mathrm{~g}$ & 40.2 & $\mathrm{a}$ & 19.8 & $\mathrm{a}$ & 7.7 & $\mathrm{a}$ \\
\hline Tebuconazole & No & 5 & 4.4 & $\mathrm{c}$ & 0.7 & abc & 6.9 & defg & 38.2 & a & 16.9 & $\mathrm{abc}$ & 4.9 & abcd \\
\hline Tebuconazole & Spray & 5 & 4.4 & $\mathrm{c}$ & 0.3 & bcd & 8.7 & $b-e$ & 35.7 & $\mathrm{a}$ & 16.0 & $\mathrm{abc}$ & 5.8 & $\mathrm{a}$ \\
\hline Myclobutanil & No & 5 & 4.6 & $\mathrm{c}$ & 0.9 & $\mathrm{ab}$ & 5.5 & efg & 36.3 & $\mathrm{a}$ & 14.6 & abcde & 3.4 & bcd \\
\hline Myclobutanil & Spray & 5 & 4.6 & $\mathrm{c}$ & 1.1 & $\mathrm{a}$ & 9.1 & bcd & 27.8 & bcd & 11.0 & cdef & 3.3 & bcd \\
\hline Cyprodinil \& fludioxonil & No & 5 & 5.2 & $\mathrm{bc}$ & 0.9 & $\mathrm{ab}$ & 7.1 & d-g & 35.3 & a & 18.6 & $\mathrm{ab}$ & 5.4 & $\mathrm{abc}$ \\
\hline Cyprodinil \& fludioxonil & Spray & 5 & 5.1 & $\mathrm{bc}$ & 0.8 & abc & 10.6 & $\mathrm{abc}$ & 22.3 & $\mathrm{~cd}$ & 8.0 & ef & 1.7 & $\mathrm{~d}$ \\
\hline Control & No & 10 & 5.2 & $\mathrm{bc}$ & 1.0 & $\mathrm{a}$ & 5.4 & $\mathrm{fg}$ & 41.7 & $\mathrm{a}$ & 20.0 & $\mathrm{a}$ & 5.3 & $a b c$ \\
\hline
\end{tabular}

${ }^{\mathrm{x}}$ Foliar disease severity rated on a scale of $0=$ no foliar symptoms to $3=$ severe symptoms. Vine vigor rated of scale of $0=$ vine dead to $5=$ most vigorous vine.

${ }^{y}$ Fruit disease severity rated on 25 berries on a scale of $0=$ no symptoms to $3=$ severe symptoms, berry inedible.

${ }^{\mathrm{z}}$ Means followed by different letters within a column and within cultivar and treatment are significantly different $(P=0.05)$ based on Fisher's LSD.

number of days between the last fungicide application and harvest, but there were no differences in the total disease scores between berries receiving their last fungicide application on the day of harvest and those that received the last application 14 to 56 days before harvest.

'Summit' berries were larger, had lower $\mathrm{pH}$, SSC, and TA values, and a higher SSC/TA ratio than 'Doreen' berries (Table 6). Berries from the sprayed side of vines were larger, had higher $\mathrm{pH}$, and lower SSC and TA values than berries from control vines or from the not sprayed side of vines. There was a highly significant cultivar by days before harvest interaction for all quality parameters. 'Doreen' berries in the spray treatment harvested 42 days after the last fungicide application had smaller berries, higher $\mathrm{pH}, \mathrm{SSC}$, and SSC/TA ratio, but a lower TA value than those with other intervals between the last fungicide application and harvest. There were significant differences in the SSC, TA, and $\mathrm{SSC} / \mathrm{TA}$ ratio due to the number of days between the last fungicide application within 'Summit' berries from the spray application; however there was not a discernable pattern to these differences.

'Summit' berries had higher fructose, glucose, total sugar, and total ellagic acid levels than 'Doreen' berries (Table 7). There were no significant differences in sugar content due to type of fungicide application (spray, no spray, or control), but ellagic acid content was lower in berries from the spray application. There were significant differences in sugar content due to the number of days between the last fungicide application and harvest with the highest concentration of glucose, fructose, and total sugar in the berries with zero and seven days between the last fungicide application and harvest. Lower levels of ellagic acid were found in berries harvested zero and 56 days after the last fungicide application than from berries harvested at other intervals. 'Doreen' berries had higher levels of each of the organic acids compared to 'Summit' (Table 8). There was not a significant main effect due to application type (spray, no spray, or control) or days between the last fungicide application and harvest in any organic acid content (data not shown); however, there were significant interactions between application type and cultivar and between application type and days before harvest in citric acid, tartaric acid and total acid content. Among the berries from the sprayed side of the vines, levels of each of the organic acids except tartaric acid were higher in 'Doreen' than in 'Summit', and there was a general trend of higher organic acid levels in berries from vines that received their last fungicide application a week or less before harvest. The lowest levels of organic acids were from berries that received their last fungicide application a week or more before harvest.

Total resveratrol content was more than three times higher in skins of berries from the "Control" and "No Spray" treatments than in those from the "Spray treatment" for each of the two cultivars (Table 9). Total and trans resveratrol were higher in skins of 'Doreen' berries than those of 'Summit' berries from each of the application treatments. Resveratrol content of berries from all the days before 
Table 5. Study 3. Effect of Cultivar and Type of Application and Interaction Between Fungicide Treatments and Days before Harvest (DBH) on Vine and Disease Assessments of Two Muscadine Grape Cultivars Grown at McNeill, MS

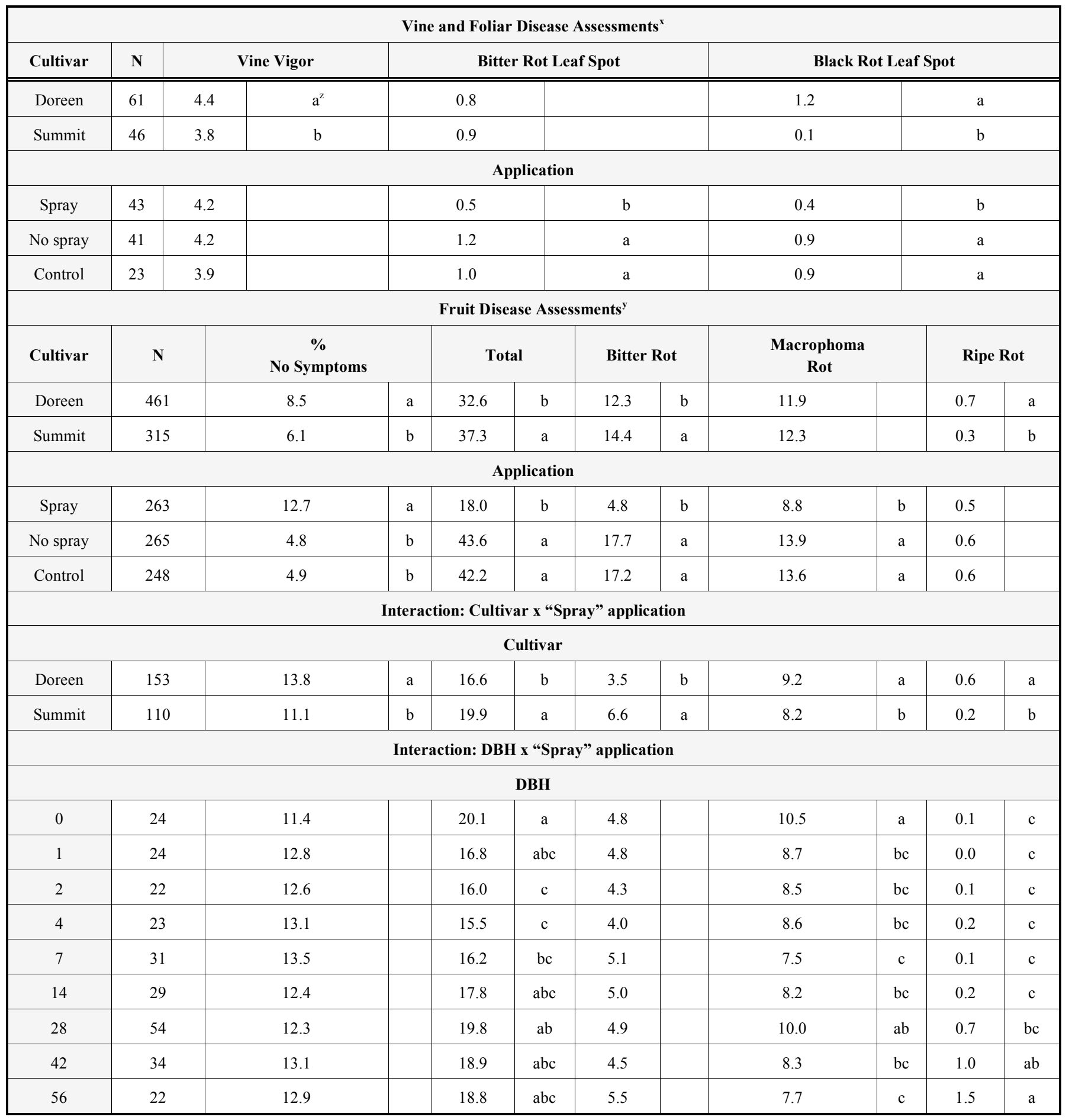

${ }^{\mathrm{x}}$ Foliar disease severity rated on a scale of $0=$ no foliar symptoms to $3=$ severe symptoms. Vine vigor rated of scale of $0=$ vine dead to $5=$ most vigorous vine.

${ }^{\mathrm{y}}$ Fruit disease severity rated on 25 berries on a scale of $0=$ no symptoms to $3=$ severe symptoms, berry inedible.

${ }^{\mathrm{z}}$ Means followed by different letters within a column and within cultivar and treatment are significantly different $(P=0.05)$ based on Fisher's LSD

harvest "spray" treatments was very low compared to that of the "no spray" and "control" treatments.

\section{Study 4}

This study compared the efficacy of four fungicides applied individually, alternated with another fungicide, or as part of a full season schedule for control of diseases of the cultivars, 'Summit' and 'Carlos'. One side of each vine was sprayed with fungicides beginning at bloom and continuing until mid-summer (early season treatment). The other half of each vine received eight fungicide treatments beginning at bloom continuing until harvest (full season treatment). There 
Table 6. Study 3. Main Effects and Interactions of Cultivar, Fungicide Spray Treatment, and Number of Days Between Last Fungicide Application and Harvest (DBH) on Berry Size (Grams/Berry), pH, Soluble Solid Concentration ( ${ }^{\circ}$ Brix), Titratable Acidity (TA), and Soluble Solid Concentration/Titratable Acidity Ratio on 'Doreen' and 'Summit' Muscadine Grapes

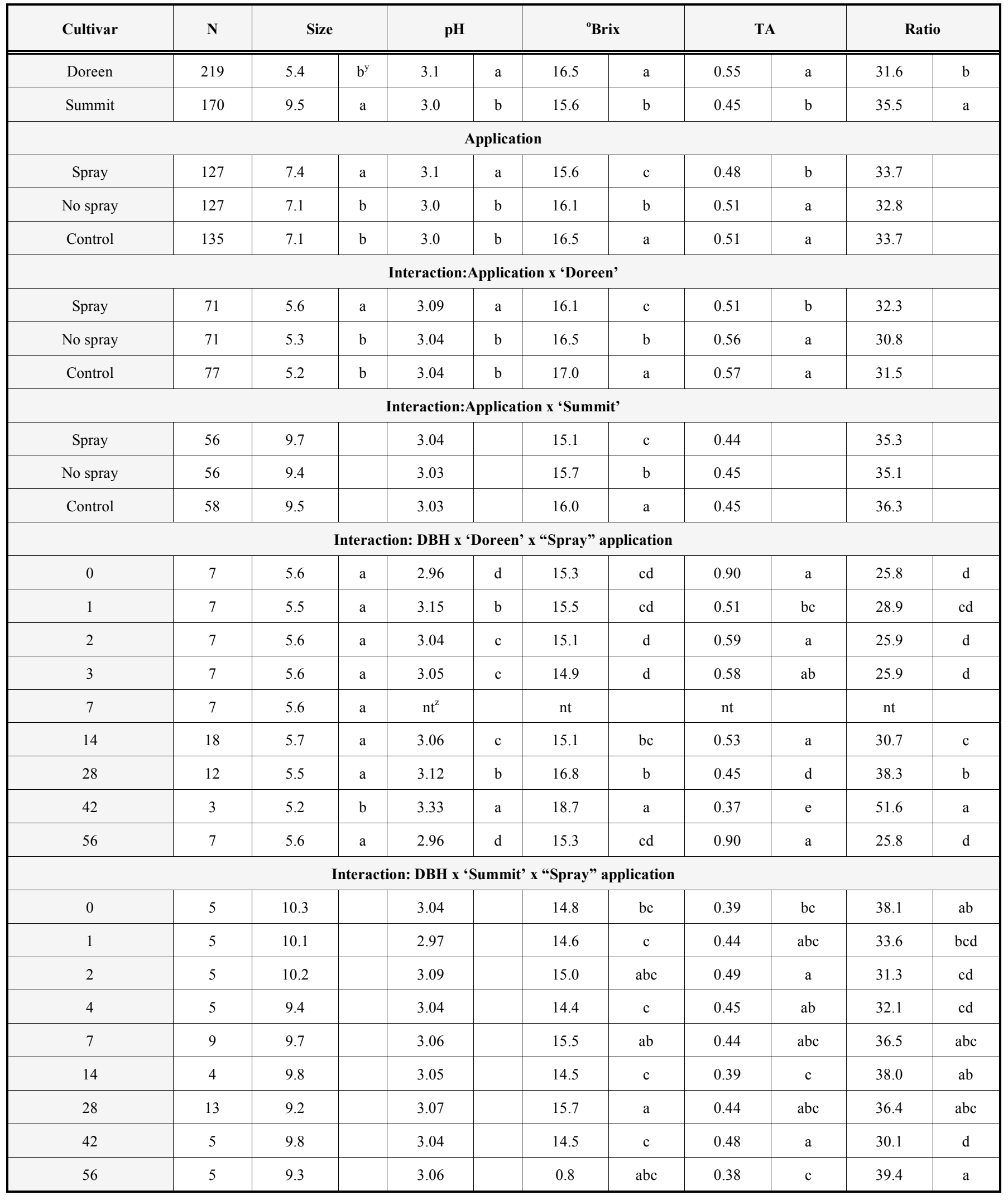


Table 7. Study 3. Main Effects of Cultivar, Application Type, and Number of Days Between Last Fungicide Application and Harvest (DBH) on Fruit Quality Analysis for Sugars (g/L) and Ellagic Acid (EA) ( $\mu \mathrm{g} / \mathrm{g}$ ) Content of Berries from Two Muscadine Grape Cultivars

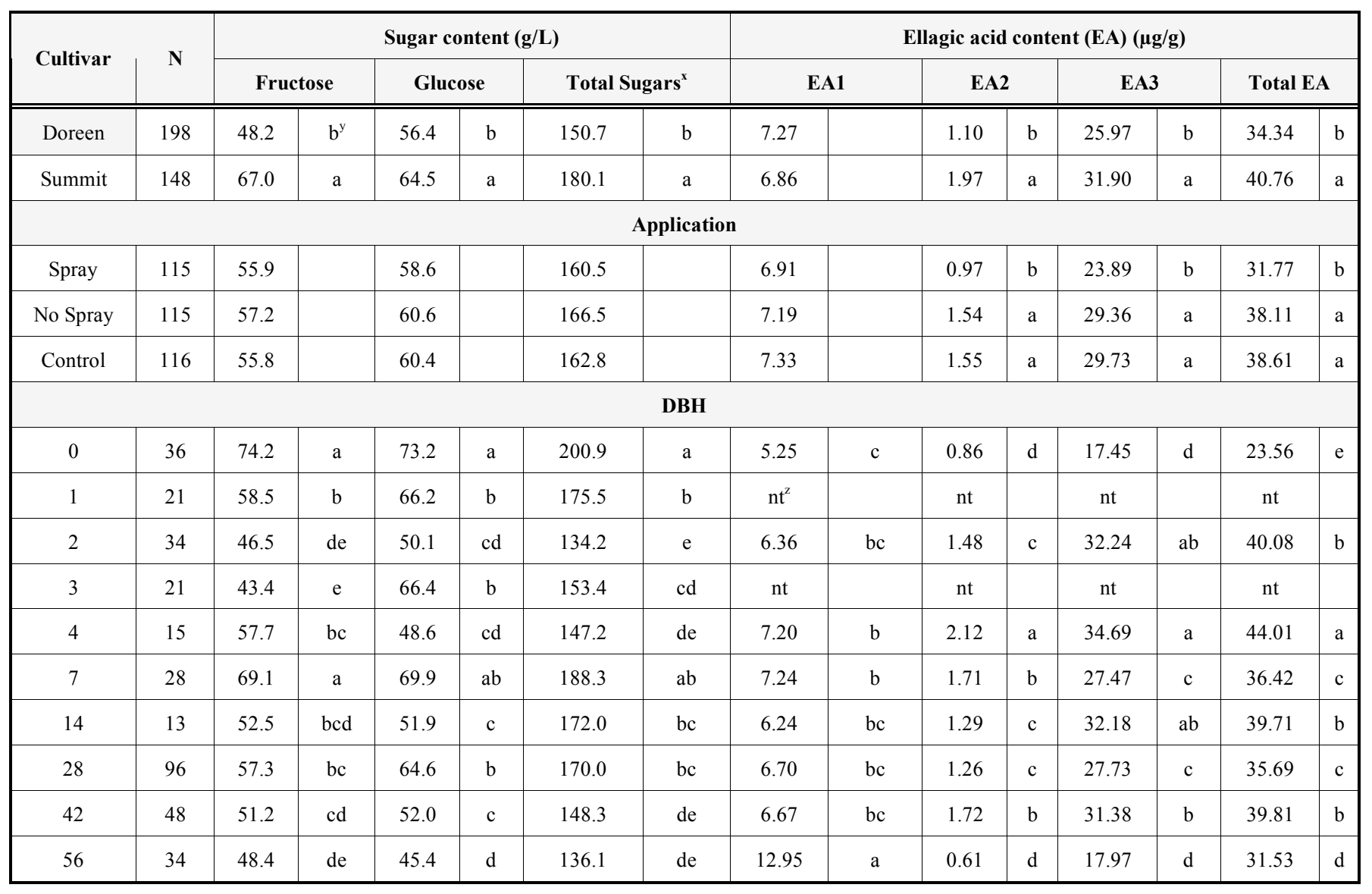

${ }^{\mathrm{x}}$ Total sugars include fructose, glucose and sucrose.

${ }^{\mathrm{y}}$ Means followed by different letters within a column and within cultivar and treatment are significantly different $(P=0.05)$ based on Fisher's (LSD).

${ }^{\mathrm{z}} \mathrm{nt}=$ not tested.

was no significant difference between early season and full season treatments in foliar disease scores or in vine vigor (Table 10). For both the early season and full season treatments, 'Carlos' received higher vine vigor, and total, bitter rot and black rot leaf spot scores than 'Summit'. There were no significant differences among early season fungicide treatments in foliar disease scores or vine vigor scores. Among the vines receiving the full season fungicide treatments the only significant differences occurred among the bitter rot leaf spot and total leaf spot scores. Compared to the control, five of the full season fungicide treatments reduced bitter rot leaf spot scores; azoxystrobin, tebuconazole, tebuconazole alternated with the cyprodinil/fludioxonil mixture, azoxystrobin alternated with the cyprodinil/fludioxonil mixture, and myclobutanil alternated with tebuconazole. Vines receiving the full season treatment azoxystrobin had a significantly lower total foliar disease score compared to the control vines.

'Carlos' berries had more asymptomatic berries, and lower Macrophoma rot scores than 'Summit' berries for both the early and full season treatments (Table 11). All full season fungicide treatments resulted in more asymptomatic berries and lower total, bitter rot and Macrophoma rot disease scores than the control, myclobutanil, and myclobutanil al- ternated with tebuconazole treatments. Within each cultivar, berries receiving the full season treatment of eight applications had more asymptomatic berries and lower total, bitter rot and Macrophoma rot scores than those receiving the early season treatment of four applications. There was not a significant difference in the percentage of asymptomatic berries between the full and early season treatments for the azoxystrobin, tebuconazole, myclobutanil, tebuconazole alternated with azoxystrobin, cyprodinil/fludioxonil mixture alternated with azoxystrobin, or control treatments.

\section{DISCUSSION AND CONCLUSION}

Berry rot diseases cause significant reductions in yield and quality of muscadine grapes grown in the southeastern U.S., but these losses may be reduced significantly by fungicide applications. Four studies were conducted to explore the relationship between disease control, berry quality and phytochemical content following full season or early season application fungicides. In each study foliar and fruit diseases were lower in the full season treatment compared to the control, and each fungicide was effective in reducing at least one disease. In each study, some treatments with fewer applications reduced fruit diseases to the same level as the full season treatment. In the first study, both the full season 
Table 8. Study 3. Main Effects and Interactions of Cultivar, Application Type, and Number of Days Between Last Fungicide Application and Harvest (DBH) on Fruit Quality Analysis for Organic Acids (Micrograms/ml) Content of Berries from Two Muscadine Grape Cultivars

\begin{tabular}{|c|c|c|c|c|c|c|c|c|c|c|c|}
\hline $\begin{array}{c}\text { Cultivar } \\
\text { Doreen }\end{array}$ & $\frac{\mathbf{N}}{198}$ & 2.21 & $a^{z}$ & 0.30 & $\mathrm{a}$ & 2.44 & $\mathrm{a}$ & 0.32 & $\mathrm{a}$ & 5.28 & $\mathrm{a}$ \\
\hline \multicolumn{12}{|c|}{ Interactions } \\
\hline Cultivar & \multicolumn{11}{|c|}{ Application $=$ Spray } \\
\hline Summit & 51 & 2.20 & & 0.17 & $\mathrm{~b}$ & 2.02 & $\mathrm{~b}$ & 0.20 & $\mathrm{~b}$ & 4.58 & $\mathrm{~b}$ \\
\hline \multicolumn{12}{|c|}{ DBH } \\
\hline 0 & 12 & 2.13 & $\mathrm{~cd}$ & 0.22 & $\mathrm{~d}$ & 2.35 & $\mathrm{~b}$ & 0.24 & $\mathrm{bc}$ & 4.95 & $\mathrm{~b}$ \\
\hline 7 & 9 & 2.31 & $\mathrm{bc}$ & 0.19 & $\mathrm{e}$ & 2.15 & $\mathrm{c}$ & 0.27 & $\mathrm{~b}$ & 4.91 & $\mathrm{~b}$ \\
\hline 14 & 4 & 2.09 & $\mathrm{~d}$ & 0.15 & $\mathrm{f}$ & 1.94 & $\mathrm{~d}$ & 0.14 & $\mathrm{~d}$ & 4.31 & $\mathrm{c}$ \\
\hline 28 & 31 & 2.11 & $\mathrm{~d}$ & 0.22 & $\mathrm{~cd}$ & 2.16 & $\mathrm{c}$ & 0.26 & $\mathrm{bc}$ & 4.74 & $\mathrm{~b}$ \\
\hline 42 & 12 & 1.89 & $\mathrm{e}$ & 0.25 & bd & 1.94 & $\mathrm{~d}$ & 0.25 & $\mathrm{bc}$ & 4.34 & $\mathrm{c}$ \\
\hline 56 & 11 & 2.02 & de & 0.21 & de & 1.87 & $\mathrm{~d}$ & 0.20 & $\mathrm{c}$ & 4.30 & $\mathrm{c}$ \\
\hline Cultivar & \multicolumn{11}{|c|}{ Application = No spray } \\
\hline Doreen & 64 & 2.23 & & 0.30 & a & 2.47 & a & 0.32 & a & 5.32 & a \\
\hline 4 & 12 & 2.43 & $\mathrm{ab}$ & 0.27 & $\mathrm{bc}$ & 2.56 & $\mathrm{a}$ & 0.28 & $\mathrm{~b}$ & 5.54 & $a b$ \\
\hline 7 & 9 & 2.33 & $\mathrm{bc}$ & 0.20 & $\mathrm{e}$ & 2.22 & $\mathrm{~b}$ & 0.23 & $\mathrm{bc}$ & 4.98 & $\mathrm{c}$ \\
\hline 14 & 4 & 1.98 & de & 0.13 & $\mathrm{f}$ & 1.79 & $\mathrm{~d}$ & 0.12 & $\mathrm{~d}$ & 4.03 & $\mathrm{~d}$ \\
\hline 28 & 31 & 2.17 & $\mathrm{~cd}$ & 0.23 & d & 2.25 & $\mathrm{~b}$ & 0.26 & $\mathrm{bc}$ & 4.91 & $\mathrm{c}$ \\
\hline 42 & 12 & 1.91 & $\mathrm{e}$ & 0.25 & $\mathrm{~cd}$ & 2.01 & $\mathrm{c}$ & 0.27 & $\mathrm{bc}$ & 4.43 & $\mathrm{~d}$ \\
\hline 56 & 11 & 0.20 & $\mathrm{e}$ & 1.94 & $\mathrm{e}$ & 1.81 & $\mathrm{~d}$ & 0.22 & $\mathrm{c}$ & 4.17 & $\mathrm{~d}$ \\
\hline
\end{tabular}

${ }^{\mathrm{z}}$ Means followed by different letters within a column are significantly different $(P=0.05)$ based on Fisher's LSD.

treatment of 9 applications applied at 10-days intervals and the azoxystrobin treatment of three applications applied at 30-day intervals resulted in significantly higher yields; lower total berry disease, bitter rot, and Macrophoma rot scores; and more asymptomatic berries than the control treatment. In the second study, four applications of the azoxystrobin, myclobutanil, and the combination fungicide, cyprodinil plus fludioxonil, applied at 30-day intervals were as effective in reducing total berry diseases as the full season schedule of
12 applications of three fungicides alternated at 10-day intervals. The lack of significant differences between foliar and fruit disease ratings of the 'spray' and 'no spray' treatments for four of the fungicides (myclobutanil, fenhexamid, tebuconazole, and the combination fungicide, cyprodinil plus fludioxonil) indicates that these fungicides did not move systemically from one side of the vine to the other. This is not surprising since fungicides are generally considered to be locally systemic. In study 3, three fungicides 
Table 9. Study 3. Interactions Between Application and Cultivar and Between Application and Days Between Last Fungicide Application and Harvest (DBH) in Total, Trans and Cis Resveratrol Content ( $\left.\mu g^{\prime} g\right)$ in Skins of 'Doreen' and 'Summit' Muscadine Grapes

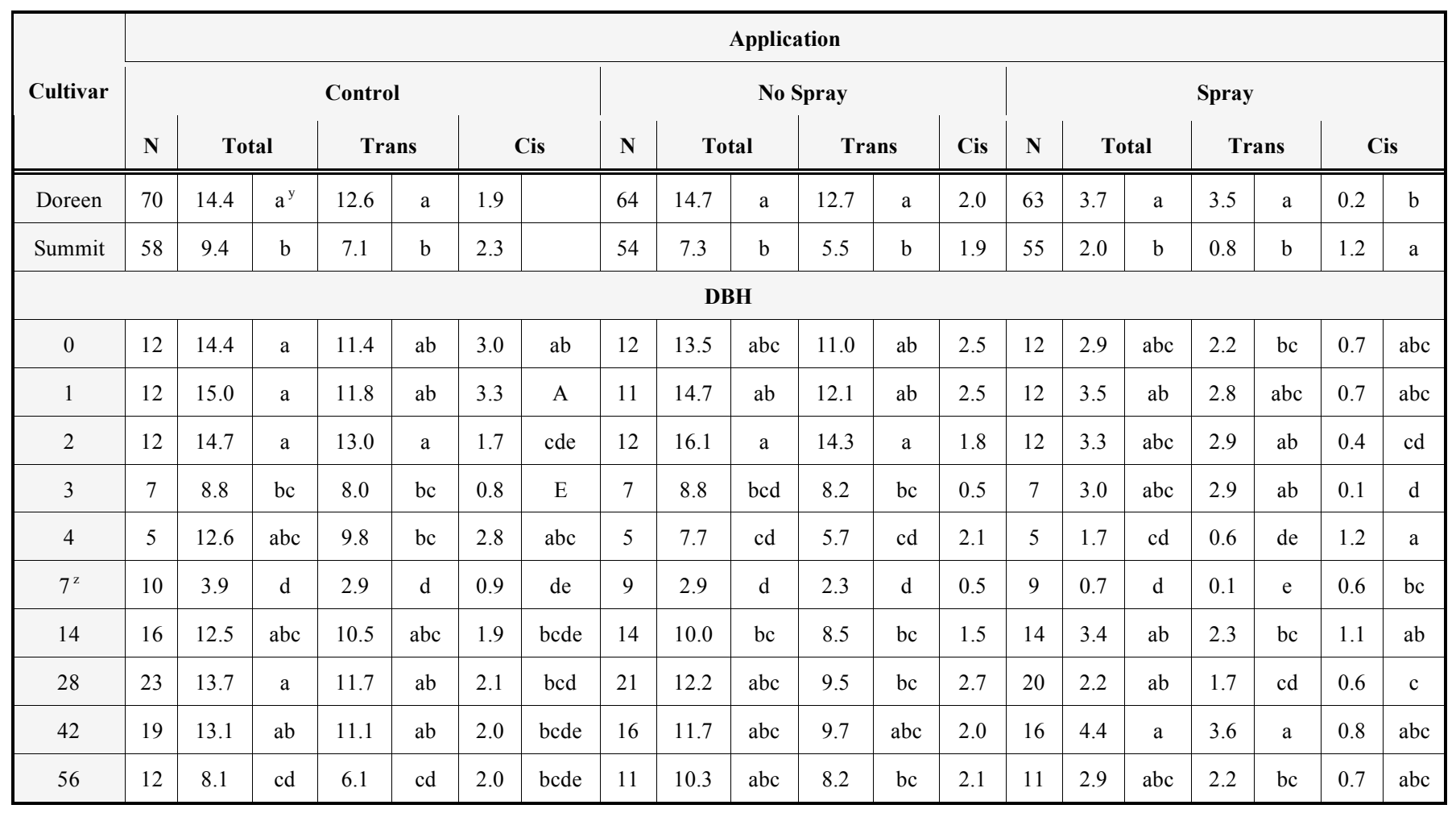

${ }^{\mathrm{y}}$ Means followed by different letters within a column are significantly different $(P=0.05)$ based on Fisher's LSD.

${ }^{\mathrm{z}}$ Values from the 7 days before harvest treatment are from 'Summit' berries only.

were applied on an alternating schedule every 10 days beginning at bloom and stopping at pre-harvest intervals of 56, $42,28,14,7,4,2,1$, and 0 days. There were no significant differences in vine vigor, foliar diseases scores, percentage of asymptomatic berries, or bitter rot scores due to the number of days between the last fungicide application and harvest. In the fourth study, there was not a significant difference in the percentage of asymptomatic berries between the full season treatment of eight applications and early season treatment of four applications for five of the fungicide treatments or in the bitter rot and total disease scores for six of the fungicide treatments indicating that early season applications of these fungicides are as effective in reducing berry diseases as the full season treatment of eight applications. The results of all four studies indicate that fungicide applications be stopped as much as six weeks before harvest without significant effects on berry diseases thus saving the grower money and reducing the effects of the fungicides on the environment.

Studies 1 and 3 also investigated the effect of the fungicide treatments on berry quality and phytochemical content. In Study 1, there were no significant differences in berry size or soluble solid content due to fungicide treatment, but significant differences were found in $\mathrm{pH}, \mathrm{TA}$, sugars, acids, and resveratrol levels of berries. Berries receiving the full season, azoxystrobin, and control fungicide treatments had highest level of each of the sugars. Total resveratrol content was lower in the skins of berries from the full season and azoxystrobin treatments than from the control and other fungicide treatments. Berries from the least efficacious treatments for berry diseases had almost ten times as much resveratrol as those from the full season and azoxystrobin treatments.

In Study 3, there were significant differences in the SSC, TA, and SSC:TA ratio of 'Summit' berries from the spray application due to the number of days between the last fungicide application; however, there was not a discernible pattern to these differences. The ellagic acid content was lower in berries from the spray treatment than from the not sprayed and control treatments. Lower levels of ellagic acid were found in berries harvested zero and 56 days after the last fungicide application than from berries harvested at other intervals. There were significant interactions between application type and days before harvest in citric acid, tartaric acid and total acid content, and a general trend of higher organic acid levels in berries from vines that received their last fungicide application a week or less before harvest. The lowest levels of organic acids were from berries that received their last fungicide application a week or more before harvest. Total resveratrol content was more than three times higher in skins of berries that did not receive fungicide sprays than in those that did. The resveratrol levels in the skins of berries from fungicide treatments were very low even if the last fungicide application was 6 or 7 weeks before harvest.

Levels of phytochemicals reported in muscadine grapes vary greatly depending on the cultivar, the part of the berry analyzed, and the analytical method. Marshall et al. [14] 
Table 10. Study 4 Foliar Disease ratings. Effect of Early Season Only (Four Applications) and Full Season (Eight Applications) Fungicide Treatments on Foliar Disease and Vine Vigor Ratings ${ }^{y}$ of Two Muscadine Grape Cultivars Grown in Vineyard at McNeill, MS

\begin{tabular}{|c|c|c|c|c|c|c|c|c|c|c|c|c|c|c|c|c|c|}
\hline \multirow{3}{*}{$\begin{array}{l}\text { Cultivar } \\
\text { Carlos }\end{array}$} & \multirow{3}{*}{$\begin{array}{l}\mathbf{N} \\
53\end{array}$} & \multicolumn{4}{|c|}{$\begin{array}{c}\text { Total } \\
\text { Leaf Spot }\end{array}$} & \multicolumn{4}{|c|}{$\begin{array}{l}\text { Bitter Rot } \\
\text { Leaf Spot }\end{array}$} & \multicolumn{4}{|c|}{$\begin{array}{l}\text { Black Rot } \\
\text { Leaf Spot }\end{array}$} & \multicolumn{4}{|c|}{$\begin{array}{l}\text { Vine } \\
\text { Vigor }\end{array}$} \\
\hline & & \multicolumn{2}{|c|}{ Early } & \multicolumn{2}{|c|}{ Full } & \multicolumn{2}{|c|}{ Early } & \multicolumn{2}{|c|}{ Full } & \multicolumn{2}{|c|}{ Early } & \multicolumn{2}{|c|}{ Full } & \multicolumn{2}{|c|}{ Early } & \multicolumn{2}{|c|}{ Full } \\
\hline & & 4.7 & $a^{z}$ & 4.3 & a & 1.9 & $\mathrm{a}$ & 1.8 & a & 1.8 & a & 1.8 & a & 3.6 & a & 3.6 & $\mathrm{a}$ \\
\hline Summit & 44 & 1.9 & $\mathrm{~b}$ & 1.6 & $\mathrm{~b}$ & 1.5 & $\mathrm{~b}$ & 1.3 & $\mathrm{~b}$ & 0.1 & $\mathrm{~b}$ & 0.0 & $\mathrm{~b}$ & 2.6 & $\mathrm{~b}$ & 2.5 & $\mathrm{~b}$ \\
\hline Azoxystrobin / azoxystrobin & 7 & 2.1 & & 1.6 & $\mathrm{~d}$ & 1.3 & & 0.9 & $\mathrm{c}$ & 0.6 & & 0.7 & & 3.6 & & 3.3 & \\
\hline $\begin{array}{l}\text { Cyprodinil \& fludioxonil / cyprodinil \& } \\
\text { fludioxonil }\end{array}$ & 8 & 3.9 & & 4.8 & $\mathrm{a}$ & 2.1 & & 2.6 & $\mathrm{a}$ & 1.3 & & 1.5 & & 3.1 & & 3.0 & \\
\hline Tebuconazole / tebuconazole & 9 & 2.8 & & 2.9 & bcd & 1.2 & & 1.2 & $\mathrm{c}$ & 1.4 & & 1.0 & & 3.2 & & 2.7 & \\
\hline Cyprodinil \& fludioxonil / myclobutanil & 7 & 3.9 & & 3.7 & $\mathrm{ab}$ & 1.9 & & 2.1 & $\mathrm{ab}$ & 1.6 & & 1.3 & & 3.4 & & 3.6 & \\
\hline Tebuconazole / azoxystrobin & 8 & 3.4 & & 3.4 & $a b c$ & 1.6 & & 1.5 & $\mathrm{bc}$ & 0.9 & & 1.3 & & 3.1 & & 3.4 & \\
\hline Tebuconazole / cyprodinil \& fludioxonil & 10 & 2.8 & & 2.3 & bcd & 1.8 & & 1.2 & $\mathrm{c}$ & 0.7 & & 1.0 & & 3.1 & & 2.9 & \\
\hline Myclobutanil / tebuconazole & 8 & 3.0 & & 2.4 & bcd & 1.4 & & 1.3 & $\mathrm{c}$ & 0.9 & & 0.6 & & 3.4 & & 3.4 & \\
\hline All four fungicides alternated & 8 & 3.9 & & 3.5 & $a b c$ & 1.8 & & 1.4 & $\mathrm{bc}$ & 1.1 & & 1.3 & & 3.3 & & 3.0 & \\
\hline Control & 9 & 4.2 & & 3.7 & $a b c$ & 2.3 & & 2.1 & $a b$ & 0.9 & & 0.9 & & 2.6 & & 2.7 & \\
\hline
\end{tabular}

${ }^{y}$ Foliar disease severity rated on a scale of $0=$ no foliar symptoms to $3=$ severe symptoms. Vine vigor rated of scale of $0=$ vine dead to $5=$ most vigorous vine.

${ }^{\mathrm{z}}$ Means followed by different letters within a column and within cultivar and treatment are significantly different $(P=0.05)$ based on Fisher's LSD.

found trans resveratrol in the skins of 20 cultivars with levels ranging from $0.0 \mu \mathrm{g} / \mathrm{g}$ in 'Alachua' to $66.0 \mu \mathrm{g} / \mathrm{g}$ in 'Pollyanna'. Trans resveratrol levels in 'Summit' skins was 6.3 $\mu \mathrm{g} / \mathrm{g}$, but the content in both the pulp and juice was $0 \mu \mathrm{g} / \mathrm{g}$. Pastrana-Bonilla et al. [33] reported resveratrol levels of 'Carlos' and 'Summit' in their study to be $0.1 \mathrm{mg} / 100 \mathrm{~g}$ in fresh whole fruit and $0.2 \mathrm{mg} / 100 \mathrm{~g}$ in the skins. Resveratrol levels reported by Stringer et al. [34] ranged from 2.5 to more than $25 \mathrm{mg} / \mathrm{kg}$ in two breeding lines while resveratrol content of 'Carlos' berries was approximately $10 \mathrm{mg} / \mathrm{kg}$. In a comparison of fungicide sprayed and unsprayed vines [26], the resveratrol content of the skins of unsprayed 'Carlos' berries was $0.33 \mu \mathrm{g} / \mathrm{g}$, 'Noble' was $9.5 \mu \mathrm{g} / \mathrm{g}$, and 'Summit" was $5.8 \mu \mathrm{g} / \mathrm{g}$. Levels of resveratrol reported in this study averaged from $1.8 \mu \mathrm{g} / \mathrm{g}$ for 'Carlos' to $14.7 \mu \mathrm{g} / \mathrm{g}$ for 'Doreen' and were within the range of that reported in other studies.

Talcott and Lee [15] reported higher levels of ellagic acid in the juice of 'Carlos' and 'Noble' muscadine grapes than in wines made from the same juice, and a much higher concentration of ellagic acid in 'Noble' juice obtained by a "hot press technique" compared to that obtained by a "cold press technique". Lee and Talcott [35] found higher concentrations of ellagic acid in the skins than in the juice or pulp of muscadine grapes and reported a total ellagic acid concentration of 18.3 and $37.5 \mathrm{mg} / \mathrm{kg}$ in the juice of ripe 'Carlos' and
'Doreen' berries. Pastrana-Bonilla et al. [33] reported ellagic acid content of fresh whole fruit to be 6.4 and 5.4 milligrams/100 grams for 'Carlos' and 'Doreen', respectively, and the ellagic acid content in the skins of these two cultivars to be 19.7 and 11.7 milligrams/100 grams. Lee et al. [36] reported that 'Noble', a red skin cultivar, had 49.7 $\mathrm{mg} / \mathrm{kg}$ of free ellagic acid compared to $13.5 \mathrm{mg} / \mathrm{kg}$ in the bronze skinned 'Doreen'. Marshall et al. [14] found ellagic acid in all 21 cultivars analyzed with total ellagic acid levels ranging from $500 \mu \mathrm{g} / \mathrm{g}$ in 'Alachua' to $5,555 \mu \mathrm{g} / \mathrm{g}$ in 'Southland'. Total ellagic acid content in 'Summit' was $1630 \mu \mathrm{g} / \mathrm{g}$ in the skins, $25 \mu \mathrm{g} / \mathrm{g}$ in the juice, and $22 \mu \mathrm{g} / \mathrm{g}$ in the pulp. Stringer et al. [34] reported a range of ellagic acid in their study from at low of $11.5 \mathrm{mg} / \mathrm{kg}$ in 'Carlos' to a high of 49.0 $\mathrm{mg} / \mathrm{kg}$ in a numbered breeding line. Total ellagic acid content in the two bronze cultivars in this study was consistent with prior studies and averaged $34.0 \mu \mathrm{g} / \mathrm{g}$ for 'Doreen' and $40.8 \mu \mathrm{g} / \mathrm{g}$ for 'Summit'.

The flavor of grapes is determined by taste components, predominantly sugars and acids, and the balance between SSC and TA [37]. The levels and ratios of sugars and acids reported for muscadine grapes have been variable. Lamikanra et al. [38] reported that the major organic acids in muscadine grapes were succinic, tartaric and malic acids with the highest acid content in the skins and the lowest in the seeds. In a comparison of 20 cultivars Striegler et al. [39] 
Table 11. Study 4 Berry Diseases. Interaction Between Number of Fungicide Applications by Cultivar and Number of Fungicide Applications by Fungicide Treatment on Percentage of Symptomless Berries and Berry Rot Disease Scores of Two Muscadine Cultivars Grown at McNeill, MS. Fungicides were Applied at 10 Day Intervals Beginning at Bloom and Ending at Harvest for a Total of 8 Applications (Full Season Treatment) or Beginning at Bloom and Ending After the Fourth Application (Early Season Treatment)

\begin{tabular}{|c|c|c|c|c|c|c|c|c|c|c|c|c|c|c|c|c|c|c|c|c|c|c|c|c|c|c|}
\hline \multirow{3}{*}{$\begin{array}{c}\text { Cultivar } \\
\text { Carlos }\end{array}$} & \multirow{3}{*}{$\frac{\mathbf{N}}{216}$} & \multicolumn{5}{|c|}{ Symptomless (\%) } & \multicolumn{5}{|c|}{ Total Disease } & \multicolumn{5}{|c|}{ Bitter Rot } & \multicolumn{5}{|c|}{ Macrophoma Rot } & \multicolumn{5}{|c|}{ Ripe Rot } \\
\hline & & \multicolumn{2}{|c|}{ Full } & \multicolumn{2}{|c|}{ Early } & & \multicolumn{2}{|c|}{ Full } & \multicolumn{2}{|c|}{ Early } & & \multicolumn{2}{|c|}{ Full } & \multicolumn{2}{|c|}{ Early } & & \multicolumn{2}{|c|}{ Full } & \multicolumn{2}{|c|}{ Early } & & \multicolumn{2}{|c|}{ Full } & \multicolumn{3}{|c|}{ Early } \\
\hline & & 10.1 & $a^{y}$ & 8.5 & $\mathrm{a}$ & $* * * \mathrm{w}$ & $1.4^{\mathrm{x}}$ & & 2 & & $* * *$ & 0.4 & & 0.6 & & $* * *$ & 0.3 & $\mathrm{~b}$ & 0.4 & $\mathrm{~b}$ & * & 0.08 & $\mathrm{a}$ & 0.09 & $\mathrm{a}$ & ns \\
\hline Summit & 185 & 9.0 & $\mathrm{~b}$ & 7.5 & $\mathrm{~b}$ & $* * *$ & 1.5 & & 2 & & $* * *$ & 0.5 & & 0.6 & & $* * *$ & 0.4 & $\mathrm{a}$ & 0.5 & $\mathrm{a}$ & $* *$ & 0.01 & $\mathrm{~b}$ & 0.01 & $\mathrm{~b}$ & ns \\
\hline \multicolumn{27}{|c|}{ Fungicide / Fungicide treatment (average of 'Carlos' and 'Summit') } \\
\hline $\begin{array}{l}\text { Tebuconazole } \\
\text { / azoxystrobin }\end{array}$ & 32 & 11.3 & a & 9.9 & $\mathrm{ab}$ & ns & 1.2 & $\mathrm{~d}$ & 1.5 & de & $*$ & 0.3 & $\mathrm{~d}$ & 0.4 & cd & $*$ & 0.3 & $\mathrm{~b}$ & 0.4 & bcd & $*$ & 0.03 & bc & 0.04 & abc & ns \\
\hline $\begin{array}{c}\text { Mixture }^{\mathrm{z}} / \\
\text { azoxystrobin }\end{array}$ & 32 & 11.1 & a & 11 & $\mathrm{a}$ & ns & 1.3 & $\mathrm{~d}$ & 1.3 & e & ns & 0.4 & cd & 0.4 & $\mathrm{~d}$ & ns & 0.3 & b & 0.3 & $\mathrm{de}$ & ns & 0.05 & $b c$ & $0 . .05$ & $a b c$ & ns \\
\hline All four & 39 & 11.0 & $\mathrm{a}$ & 9.4 & $a b c$ & $*$ & 1.2 & $d$ & 1.4 & de & ns & 0.3 & $\mathrm{~cd}$ & 0.4 & $\mathrm{~cd}$ & ns & 0.2 & $\mathrm{~b}$ & 0.3 & cde & $*$ & 0.03 & bc & 0.01 & $\mathrm{c}$ & ns \\
\hline $\begin{array}{l}\text { Mixture / } \\
\text { mixture }\end{array}$ & 36 & 10.9 & $\mathrm{a}$ & 8.4 & $b-f$ & $* * *$ & 1.2 & $\mathrm{~d}$ & 1.5 & cde & $* * *$ & 0.4 & cd & 0.5 & bcd & $*$ & 0.3 & b & 0.3 & $\mathrm{de}$ & ns & 0.00 & $\mathrm{c}$ & 0.02 & bd & ns \\
\hline $\begin{array}{l}\text { Azoxystrobin } \\
\text { / azoxystrobin }\end{array}$ & 32 & 10.2 & $\mathrm{a}$ & 9.2 & $a-d$ & ns & 1.3 & $\mathrm{~cd}$ & 1.3 & e & ns & 0.4 & cd & 0.4 & $\mathrm{~d}$ & ns & 0.2 & b & 0.2 & d & ns & 0.09 & $a b$ & 0.03 & $a b c$ & ns \\
\hline $\begin{array}{l}\text { Azoxystrobin } \\
\text { myclobutanil }\end{array}$ & 34 & 10.2 & $\mathrm{a}$ & 7 & efg & $* *$ & 1.2 & $d$ & 1.9 & $\mathrm{bc}$ & $* * *$ & 0.3 & d & 0.6 & $\mathrm{~b}$ & $* * *$ & 0.2 & b & 0.5 & $a b c$ & $* * *$ & 0.02 & bc & 0.08 & $a b c$ & ns \\
\hline $\begin{array}{c}\text { Mixture / } \\
\text { myclobutanil }\end{array}$ & 29 & 10.2 & $\mathrm{a}$ & 7.8 & c-g & $*$ & 1.3 & $\mathrm{~d}$ & 1.6 & b-e & $*$ & 0.4 & cd & 0.6 & $\mathrm{bc}$ & $*$ & 0.3 & b & 0.4 & cde & ns & 0.02 & $b c$ & 0.06 & $a b c$ & ns \\
\hline $\begin{array}{c}\text { Tebuconazole } \\
\text { / Mixture }\end{array}$ & 32 & 10.1 & $\mathrm{a}$ & 7.5 & d-g & $* * *$ & 1.3 & $d$ & 1.7 & bcd & $* * *$ & 0.4 & $\mathrm{~cd}$ & 0.6 & $\mathrm{~b}$ & $*$ & 0.3 & $\mathrm{~b}$ & 0.4 & cde & $\mathrm{ns}$ & 0.02 & bc & 0.03 & $a b c$ & ns \\
\hline $\begin{array}{l}\text { Tebuconazole } \\
\text { tebuconazole }\end{array}$ & 31 & 10.0 & $a b$ & 8.8 & $a-e$ & ns & 1.4 & $\mathrm{~cd}$ & 1.6 & b-e & ns & 0.5 & cd & 0.6 & $\mathrm{bc}$ & ns & 0.4 & b & 0.4 & $\mathrm{~cd}$ & ns & 0.02 & bc & 0.07 & $a b c$ & ns \\
\hline $\begin{array}{l}\text { Myclobutanil } \\
\text { tebuconazole }\end{array}$ & 32 & 8.2 & bc & 6.5 & g & $*$ & 1.7 & bc & 2.0 & $a b$ & ns & 0.5 & bc & 0.7 & $\mathrm{~b}$ & ns & 0.5 & $\mathrm{a}$ & 0.6 & $\mathrm{a}$ & ns & 0.07 & $a b c$ & 0.09 & a & ns \\
\hline $\begin{array}{l}\text { Myclobutanil } \\
\text { myclobutanil }\end{array}$ & 35 & 7.1 & $\mathrm{c}$ & 6.8 & fg & ns & 2.0 & $a b$ & 2.0 & $a b$ & ns & 0.6 & $a b$ & 0.7 & $\mathrm{~b}$ & ns & 0.5 & $\mathrm{a}$ & 0.6 & $\mathrm{ab}$ & ns & 0.13 & $\mathrm{a}$ & 0.09 & $\mathrm{ab}$ & ns \\
\hline Control & 37 & 5.1 & d & 4.5 & $\mathrm{~h}$ & ns & 2.2 & $\mathrm{a}$ & 2.3 & $\mathrm{a}$ & ns & 0.8 & $\mathrm{a}$ & 0.9 & $\mathrm{a}$ & ns & 0.6 & $\mathrm{a}$ & 0.6 & $\mathrm{a}$ & ns & 0.07 & $a b c$ & 0.07 & $a b c$ & ns \\
\hline
\end{tabular}

${ }^{\mathrm{w}}$ Significance between the full season application and the early season application is indicated by $*=$ significant at $0.05, * *$ significant at 0.01 , $* * *$ significant at 0.001 , and ns $=$ not significant.

${ }^{\mathrm{x}}$ Fruit disease severity rated on 25 berries on a scale of $0=$ no symptoms to $3=$ severe symptoms, berry inedible.

${ }^{y}$ Means followed by different letters within a column and within cultivar and treatment are significantly different $(P=0.05)$ based on Fisher's LSD.

${ }^{\mathrm{z}}$ Mixture $=$ commercial mixture of cyprodinil and fludioxonil.

found the highest level of soluble solids in three black skinned cultivars, 'Ison', 'Supreme', and 'Southern Home'. Fruit size and SSC reported in their study was 3.7 grams/berry and $17.0 \%$ for 'Carlos'; 3.7 grams/berry and $14.9 \%$ for 'Doreen', and 6.6 grams/berry and $18.3 \%$ for Summit'. They concluded that "press" material (the residue left after the juice is removed) offers the best potential source of nutraceutical compounds from muscadine grape. Size and SSC of muscadine grapes in this study averaged 4.8 $\mathrm{g} /$ berry and $12.5 \%$ for 'Carlos', $5.1 \mathrm{~g} /$ berry and $16.9 \%$ for 'Doreen', and $9.8 \mathrm{~g} /$ berry and $15.3 \%$ for 'Summit'. Fruit size for all three cultivars in this study was larger and the SSC was within $\pm 4.5 \%$ of that reported by Striegler et al. [39].

The data from these four studies indicate that the number of fungicide applications required for control of muscadine grape diseases can be reduced without an increase in berry rot disease severity. The most effective fungicides reduced berry diseases with as few as four applications compared to 12 applications in the full season schedules. Fungicides that controlled berry disease had an effect on berry quality including lowering the content of the beneficial phytoalexin, resveratrol. 


\section{CONFLICT OF INTEREST}

The author(s) confirm that this article content has no conflicts of interest.

\section{ACKNOWLEDGEMENT}

Thanks to Kermis Myrick and Wanda S. Elliott for technical assistance with this project. Mention of trade names or commercial products in this article is solely for the purpose of providing specific information and does not imply recommendation or endorsement by the U. S. Department of Agriculture.

\section{ABBREVIATIONS}

$$
\begin{array}{ll}
\text { DBH } & =\text { Days before harvest } \\
\text { HPLC } & =\text { High performance liquid chromatography } \\
\text { LSD } & =\text { Least significant difference } \\
\text { SSC } & =\text { Soluble solid concentration } \\
\text { TA } & =\text { Titratable acidity }
\end{array}
$$

\section{REFERENCES}

[1] Olien, W.C. In Muscadine Grapes; Basiouny, F.M.; Himelrick, D.G., Eds., ASHS Press: Alexandria, VA, 2001; Introduction to Muscadine Grapes, pp. 1-13.

[2] Pearson, R.C.; Goheen, A.C., Eds.; Compendium of Grape Diseases; American Phytopathological Society: St. Paul, MN, 1988.

[3] Basiouny, F.M. In Muscadine Grapes; Basiouny, F.M.; Himelrick, D.G., Eds., ASHS Press: Alexandria, VA, 2001; Physiology and postharvest technology, pp. 273-310.

[4] Ector, B.J.; Magee, J.B.; Hegwood, C.P.; Coign, M.J. Resveratrol concentration in muscadine berries, juice, pomace, purees, seeds, and wines. Am. J. Enol. Vitic., 1996, 47, 57-62.

[5] McMurtrey, K.D.; Watkins, T.R. In Wine: Nutritional and Therapeutic Benefits; Watkins, T.R., Ed.; American Chemical Society, Washington, DC, 1997; Resveratrol in wine, ACS Symposium Series 661 , pp. 44-55.

[6] Threlfall, R.T.; Morris, J.R.; Mauromoustakos, A. Effect of variety, ultraviolet light exposure, and enological methods on the transresveratrol level of wine. Am. J. Enol. Vitic., 1999, 50(1), 57-64.

[7] Arichi, H.; Kimura, Y.; Okuda, H.; Baba, K.; Kozawa, M.; Arichi, S. Effects of stilbene components of the roots of Polygonum cuspidatum Sief et Zucc. on lipid metabolism. Chem.Phar. Bull., 1982, 30, 1766-1770.

[8] Kimura, Y.; Okuda, H.; Arichi, S. Effects of stilbenes on arachidonate metabolism in leukocytes. Biochim. Biophys. Acta, 1985, 834, 275-278.

[9] Pace-Asciak, C.R.; Hahn, S.; Diamandis, E.P.; Soleas, G.; Goldberg, D.M. The red wine phenolics trans-resveratrol and quercetin block human platelet aggregation and eicosanoid synthesis: implications for protection against coronary heart disease. Clin. Chim. Acta, 1995, 235, 207-219.

[10] Frankel, E.N.; Waterhouse, A.L.; Kinsella, J.E. Inhibition of human LDL oxidation by resveratrol. Lancet, 1993, 341, 1103-1104.

[11] Jang, M.; Cai, L.; Udeani, G.O.; Slowing, K.V.; Thomas, C.F.; Beecher, C.W.W.; Fong, H.H.S.; Farnsworth, N.R.; Kinghorn, A.D.; Mehta, R.G.; Moon, R.C.; Pezzuto, J.M. Cancer chemopreventive activity of resveratrol, a natural product derived from grapes. Science, 1997, 275 (10 Jan), 218-220.

[12] Jang, M.L; Pezzuto, J.M. Cancer chemopreventative activity of resveratrol. Drug Exp. Can. Res., 1999, 25 (2-3), 65-77.

[13] Mgbonyebi, O.P.; Russo, J.; Russo, I.H. Antiproliferative effect of synthetic resveratrol on human breast epithelial cells. Int. J. Oncol., 1998, 12, 865-869.
[14] Marshall, D.A.; Stringer, S.J.; Spiers, J.D. Stilbene, ellagic acid, flavonol, and phenolic content of muscadine grape (Vitis rotundifolia Michx.) cultivars. Pharm. Crops, 2012, 3, 69-77.

[15] Talcott, S.T.; Lee, J-H. Ellagic acid and flavonoid antioxidant content of muscadine wine and juice. J. Agric. Food Chem., 2002, 50, 3186-3192.

[16] Pezzuto, J.M. Grapes and Human Health: A Perspective. J. Agric. Food Chem., 2008, 56, 6777-6784.

[17] Creasy, L.L.; Coffee, M. Phytoalexin production potential of grape berries. J. Am. Soc. Hortic. Sci., 1988, 113, 230-234.

[18] Fumagalli, F.; Rossoni, M.; Iriti, M.; di Gennaro, A.; Faoro, F.; Borron, E.; Borgo, M.; Scienza, A.; Sala, A.; Folco, G. From field to health: a simple way to increase the nutraceutical content of grape as shown by NO-dependent vascular relaxation. J. Agric. Food Chem., 2006, 54, 5344-5349.

[19] Hain, R.; Reif, H.J.; Krause, E.; Langebartels, R.; Kindl, H.; Vornam, B.; Wiese, W.; Schmelzer, E.; Schreier, P.H.; Stöcker, R.H.; Stenzel, K. Disease resistance results from foreign phytoalexin expression in a novel plant. Nature, 1993, 361, 153-156.

[20] Hipskind, J.D.; Paiva, N.L. Constitutive accumulation of a resveratrol-glucoside in transgenic alfalfa increases resistance to Phoma medicaginis. Mol. Plant-Microbe Interact., 2000, 13, 551-562.

[21] Jeandet, P.A.; Douillet-Breuil, C.; Bessis, R.; Debord, S.; Sbaghi, M.; Adrian, M. Phytoalexins from the Vitaceae: biosynthesis, phytoalexin gene expression in transgenic plants, antifungal activity, and metabolism. J. Agric. Food Chem., 2002, 50, 2731-2741.

[22] Schwekendiek, A.; Pfeffer, G.; Kindl, H. Pine stilbene synthase cDNA, a tool for probing environmental stress. FEBS Lett., 1992, 301, 41-44.

[23] Langcake, P.; Pryce, R.J. The production of resveratrol by Vitis vinifera and other members of the Vitaceae as a response to infection or injury. Physiol. Plant Pathol., 1976, 9, 77-86.

[24] Dai, G.H.; Andary, C.; Mondolot-Cosson, L.; Bourals, D. Histochemical studies of the interaction between three species of grapevine, Vitis vinifera, $V$. rupestris and $V$. rotundifolia and the downy mildew fungus, Plasmopara viticola. Physiol. Mol. Plant Pathol., 1995, 45, 177-188.

[25] Dercks, W.; Creasy, L.L.; Luczka-Bayles, C.J. In Handbook of Phytoalexin Metabolism and Action; Daniel, M.; Purkayastha, R.P., Eds.; Marcel Decker: New York, Stilbene phytoalexins and disease resistance in Vitis, 1995; pp. 287-315.

[26] Magee, J.B.; Smith, B.J.; Rimando, A. Resveratrol content of muscadine berries is affected by disease control spray program. Hortic. Sci., 2002, 37, 358-361.

[27] Chen, J.; Copes, W.E.; Miller, R.W.; Lamikanra, O. In Muscadine Grapes; Basiouny, F.M.; Himelrick, D.G., Eds; ASHS Press, Alexandria, VA, Diseases, 2001; pp. 189-239.

[28] Clayton, C.N. Diseases of Muscadine and Bunch grapes in North Carolina and their control. N.C. Agric. Exp. Stn. Bull. Raleigh, NC, 1975, p. 451

[29] Kummuang, N.; Smith, B.J.; Diehl, S.V.; Graves, Jr., C.H. Muscadine grape berry rot diseases in Mississippi: disease identification and incidence. Plant Dis., 1996, 80, 238-243.

[30] Braswell, J.; Stringer, S.J.; Sampson, B.; Ingram, D. Establishment and Production of Muscadine Grapes, Publication 2290, Mississippi State Univ. Extension Service, Mississippi State, MS, 2006.

[31] Dercks, W.; Creasy, L.L. The significance of stilbene phytoalexins in the Plasmopara viticola-grapevine interaction. Physiol. Mol. Plant Pathol., 1989, 34, 189-202.

[32] Kalt, W.; McDonald, J.E. Chemical composition of lowbush blueberry cultivars. J. Am. Soc. Hortic. Sci., 1996, 121,142-146.

[33] Pastrana-Bonilla, E.; Akoh, C.C.; Sellappan, S.; Krewer, G. Phenolic content and antioxidant capacity of muscadine grapes. J. Agric. Food Chem., 2003, 51, 5497-5503.

[34] Stringer, S.J.; Marshall, D.A.; Perkins-Veazie, P. Nutraceutical compound concentrations of muscadine (Vitis rotundifolia Michx.) grape cultivars and breeding lines. Acta Hortic., 2009, 841, 553556.

[35] Lee, J-H.; Talcott, S.T. Fruit maturity and juice extraction influences ellagic acid derivatives and other antioxidant polyphenolics in muscadine grapes. J. Agric. Food Chem., 2004, 52, 361-366. 
[36] Lee, J-H.; Johnson, J.V.; Talcott, S.T. Identification of ellagic acid conjugates and other polyphenolics in muscadine grapes by HPLCESI-MS. J. Agric. Food Chem., 2005, 53, 6003-6010.

[37] Sonego, L.; Lurie, S.; Zuthi, Y.; Kaplonov, T.; Ben-Arie, R.; Kosto, I. Factors affecting taste scores of early season seedless table grape cv. Mystery and Prime. J. Agric. Food Chem., 2002, 50, 544-548.
[38] Lamikanra, L.; Unyang, I.D.; Leong, S. Distribution and effect of grape maturity on organic acid content of red muscadine grapes. $J$. Agric. Food Chem., 1995, 43, 3026-3028.

[39] Striegler, R.K.; Carter, P.M.; Morris, J.R.; Clark, J.R.; Threlfall, R.T.; Howard, L.R. Yield, quality, and nutraceutical potential of selected muscadine cultivars grown in southwestern Arkansas. Hor tic. Technol., 2005, 15(2), 276-284.

Received: August 30, 2013

Revised: October 25, 2013

Accepted: October 27, 2013

(C) Barbara J. Smith; Licensee Bentham Open.

This is an open access article licensed under the terms of the Creative Commons Attribution Non-Commercial License (http://creativecommons.org/licenses/by-nc/3.0/) which permits unrestricted, non-commercial use, distribution and reproduction in any medium, provided the work is properly cited. 